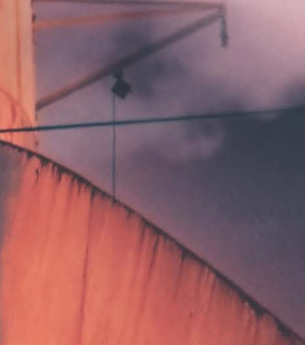

African perspectives on selected marine, maritime and

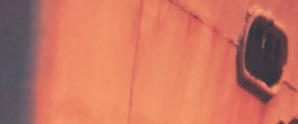

)
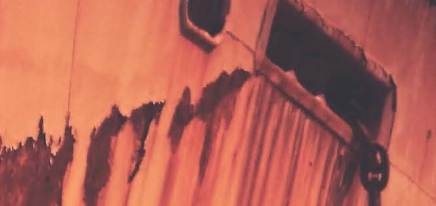

:
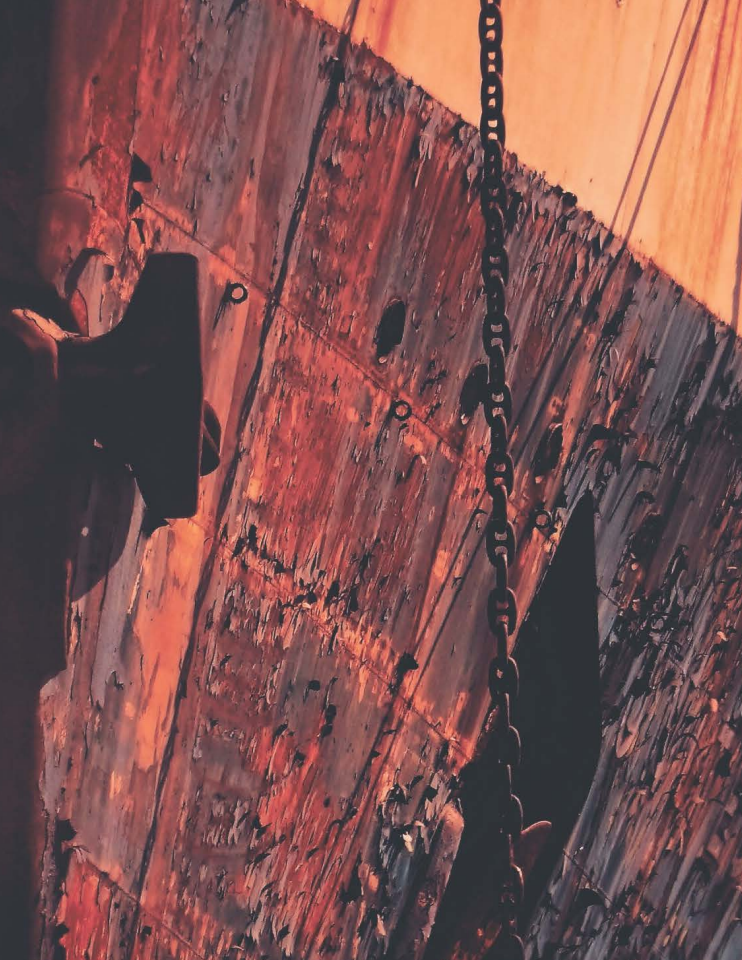

Patrick Vrancken \& Char! Hugo (Eds)

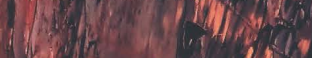

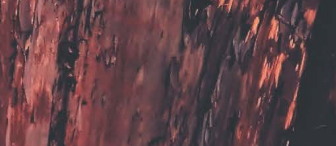

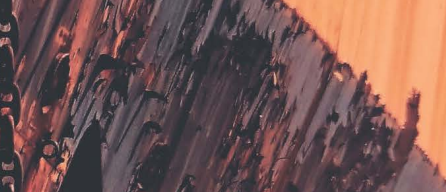




\title{
CONTRIBUTION LIABILITY \\ COMPENSATION FOR SHIP-SOURCED OIL POLLUTION DAMAGE IN SOUTH AFRICA
}

\author{
CHLOE JOHANNES ${ }^{\star}$
}

* Lecturer of Mercantile Law, University of Johannesburg. 


\section{INTRODUCTION}

The transportation of oil by sea poses the risk of marine oil pollution. Approximately half of global crude oil is transported by sea. ${ }^{1}$ In 2018 , the United Nations Conference on Trade and Development estimated the global crude oil trade at 1.9 billion tonnes. ${ }^{2}$ In the same year, tanker shipments of oil, gas and chemicals accounted for 29 percent of the globally traded goods transported by sea. ${ }^{3}$ As international maritime trade continues to grow, ships increase in number and size. ${ }^{4}$ Larger quantities of bunker fuel are being carried over the sea to fuel those vessels, ${ }^{5}$ a factor that increases the risk of marine oil pollution. Although large-scale ship-sourced oil pollution incidents have decreased over the last few decades,${ }^{6}$ the threat of oil pollution persists because a single incident can cause significant damage. Following such an incident, costly clean-up measures may be required, the marine environment and marine organisms may be adversely impacted and individuals may suffer damage to their property, other economic loss or injury to their health. In addition, the whole national economy of the Coastal State may be negatively affected as industries such as tourism and fisheries, which often make significant contributions to economic growth, suffer a (hopefully temporary) decline. ${ }^{7}$ The large quantities of oil imported into South Africa, make our economy and marine and coastal environment vulnerable to pollution damage. ${ }^{8}$ Moreover, the Cape of Good Hope, at the south-western tip of South Africa, is an important global trade route acting as a point of transit for oil tanker

1 United Nations Conference on Trade and Development (UNCTAD) "Liability and compensation for ship source oil pollution: an overview of the international legal framework for oil pollution damage from tankers" (2012) 1 https://unctad.org/en/PublicationsLibrary/dtltlb20114_en.pdf (25-01-2019).

2 UNCTAD “Review of maritime transport” (2019) 9 https://unctad.org/en/PublicationsLibrary/rmt2019_en.pdf (05-09-2020).

3 ibid 4.

$4 \quad \mathrm{UNCTAD}(\mathrm{n}$ 1) 5.

5 ibid 1.

6 ibid 5.

7 ibid 1.

8 In 2018, the South African oil industry received over 20 million tonnes of contributing oil. See International Oil Pollution Compensation Funds (IOPC) “Annual Report” (2019) 28 https://iopcfunds.org/wp-content/ uploads/2020/03/Final-Annual-Report_2019_e-1.pdf (31-07-2020). 
shipments en route to the East and West ${ }^{9}$ carried by tankers that are too large to transit through the Suez Canal. ${ }^{10}$

Oil incidents that have occurred in South Africa include spills from the Castillo de Bellver, ${ }^{11}$ the Apollo ${ }^{12}$ and the Treasure. ${ }^{13}$ The Apollo and the Treasure required costly clean-up measures and had significant impacts on the marine environment and marine life. Indeed, the oil contamination caused by the Apollo led to an enormous environmental catastrophe killing thousands of seabirds, including endangered African penguins, ${ }^{14}$ while the grounding of the Treasure caused the worst oiling incident in South Africa yet as more than 19000 penguins were oiled, of which approximately 2000 adults and 4350 chicks died. ${ }^{15}$

As a result of the adverse economic and environmental impacts of oil spills, liability for oil pollution damage must be clearly defined. Victims of oil pollution damage need to know where to turn for compensation of their losses.

9 US Energy Information Administration, International Energy Statistics “World Oil Transit Chokepoints” (2017) 18 https://www.eia.gov/international/content/analysis/special_topics/World_Oil_Transit_Chokepoints/wotc.pdf (29_ 08-2020).

10 Holloway "South Africa's practical approach to dealing with oil pollution prevention and ships in need of assistance" 2005 China Ocean's LR 141 141. In 2015, the crude oil transiting around the Cape made up approximately 9 percent of globally traded oil transported by sea. See US Energy Information Administration (n 9) 18.

11 The Spanish registered tanker MV Castillo de Bellver caught fire approximately 70 nautical miles WNW of Cape Town and, seven hours later, the vessel broke in two. The following morning, the stern section capsized and sank some 24 nautical miles due west of Saldanha Bay. The Castillo de Bellver was carrying 242262 tonnes of light crude oil of which approximately between 160000 and 190000 tonnes were discharged into the ocean. The oil spill occurred near an ecologically sensitive area and in the locality of important commercial fishing grounds. Little environmental damage, however, occurred because favourable wind conditions drove the oil slick away from the shore into the Benguela current thus resulting in its natural dispersal. See Moldan, Jackson, McGibbon and Van Der Westhuizen "Some aspects of the Castillo de Bellver oil spill" 1985 Marine Pollution Bulletin 9797.

12 The Apollo Sea sank off the coast of Cape Town between Dassen Island and Robben Island. Approximately 2400 tonnes of heavy fuel oil were spilled and washed ashore at both Dassen and Robben Islands. Some 10000 African penguins were oiled, resulting in the worst oiling incident in South Africa at the time. 4718 of the collected oiled birds were successfully cleaned by the Southern African National Foundation for the Conservation of Coastal Birds (SANCCOB) and later returned to the wild. See Wolfaardt, Underhill, Altwegg,Visagie and Williams "Impact of the Treasure oil spill on African penguins Spheniscus demersus at Dassen Island: case study of a rescue operation" 2008 Afr J Mar Sci 405 405-406; Crawford, Davis, Harding, Jackson, Leshoro, Meÿer, Randall, Underhill, Upfold, Van Dalsen, Van der Merwe, Whittington, Williams and Wolfaardt "Initial effects of the 'Treasure' oil spill on seabirds off western South Africa”2000 SA J Mar Sci 157159.

13 In June 2000, the bulk ore carrier MVTreasure sank off western South Africa between Dassen and Robben islands (important bird areas). The MVTreasure was carrying 1344 tonnes of heavy fuel oil, 56 tonnes of diesel oil and 64 tonnes of lubricating oil of which all excluding 205 tonnes of heavy fuel were discharged into the waters. More than 19000 penguins (mostly African Penguins) were oiled as a result of the spill. See Crawford et al (n 12) 157 and 169 ; Wolfaardt et al (n 12) 406 and 414.

14 Crawford et al (n 12) 159. Following the Apollo, 5000 birds died, many of them during transit to SANCCOB rescue stations or shortly after arrival at the stations.

15 Wolfaardt et al (n 12) 405-406 and 414; Crawford et al (n 12) 157 and 171. 
Questions of liability may result in protracted litigation, which can hinder and delay compensation for victims of oil pollution damage. Following the ecological catastrophe caused by Torrey Canyon, ${ }^{16}$ the global community recognised the need for international co-operation regarding oil pollution and, under the auspices of the International Maritime Organization (IMO) ${ }^{17}$ the 1969 International Convention on Civil Liability for Oil Pollution Damage (CLC 1969) ${ }^{18}$ was adopted. CLC 1969 places strict liability on tanker owners for oil pollution damage, ${ }^{19}$ accompanied by the right to limit such liability to financial caps set out in the Convention. ${ }^{20}$ Tanker owners are required to obtain and carry evidence of insurance covering their liability. ${ }^{21}$ Part of the compromise that led to the adoption of the CLC 1969 was the establishment of an international fund, to which the oil industry would contribute, by means of the 1971 International Convention on the Establishment of an International Fund for Compensation for Oil Pollution Damage (FUND 1971). ${ }^{22}$

The Amoco Cadiz oil spill occurred less than a decade after the adoption of FUND 1971.23 The spill revealed that the limits of liability under CLC 1969 and FUND 1971 were not enough to adequately cover the costs of an oil spill that large. ${ }^{24}$ This led, in 1992, to the amendment of the compensation regime created in terms of the two conventions by means of two protocols which entered into

16 In March 1967, the Liberian registered tanker Torrey Canyon ran aground on the Seven Stones Reef near Lands End in Cornwall. The tanker was carrying 117000 tonnes of Kuwait crude oil of which approximately 80000 tonnes were discharged into the sea. This resulted in the contamination of beaches on the Cornish coast, a threat to the French coast, contaminated oyster beds and fisheries and extensive damage to bird life. See Nanda "The Torrey Canyon disaster: Some legal aspects” 1967 Denver LJ 400 400-401.

Gurumo and Han "The role of international oil pollution liability legislation in the protection of the marine environment” 2012 IJESD 183184.

19 art III.

20 art V.

21 artVII.

221110 UNTS 57, (1972) 11 ILM 284. Adopted: 18-12-1971; EIF: 16-10-1978; NLIF: 24-05-2002. See the sixth paragraph of the preamble to the Convention.

23 In March 1978, the Amoco Cadiz ran aground 130 miles off the coast of Brittany and spilled 230000 tonnes of crude oil into the surrounding waters. The spill resulted in the contamination of the French coastline, contaminating beaches and fishing ground. This was, at the time, the worst oil tanker casualty. See Bartlett "In re Oil Spill by the Amoco Cadiz - choice of law and a pierced corporate veil defeat the 1969 Civil Liability Convention" 1985 Mar Law 1 1; Rosenthal and Raper "Amoco Cadiz and limitation of liability for oil spill pollution: Domestic and international solutions” 1985 Virginia J Nat Res L 259 259-260.

24 Faure and Hui "Economic analysis of compensation for oil pollution” 2006 J Mar L \& Com 179196. 
force in 1996. ${ }^{25}$ These protocols increased the financial limits for compensation of oil pollution damage ${ }^{26}$ and extended the geographical area within which tanker owners incur strict liability for pollution damage. ${ }^{27}$ The amended conventions are known as the 1992 International Convention on Civil Liability for Oil Pollution Damage (CLC 1992) ${ }^{28}$ and the 1992 International Convention on the Establishment of an International Fund for Compensation for Oil Pollution Damage (FUND 1992). ${ }^{29}$ The International Oil Pollution Compensation Fund 1992 ("the Fund") ${ }^{30}$ is managed by a Secretariat located in London ${ }^{31}$ and provides compensation where cover under CLC 1992 is insufficient. ${ }^{32}$ Through becoming a state party to FUND 1992, a state becomes a party to the Fund. ${ }^{33}$ FUND 1971 ceased to be of force in 2002 when the number of States parties became less than $25 .{ }^{34}$ Twelve years later, the International Oil Pollution Compensation Fund 1971 ceased to exist. ${ }^{35}$ A large number of States, including South Africa, have denounced CLC 1969. ${ }^{36}$

The Civil Liability Act was enacted to give effect in South African law to the 1992 Protocol that amended CLC 1969 and to provide for matters related therewith, ${ }^{37}$ while the Compensation Act gives effect to the 1992 Protocol that amended FUND 1971 and provides for matters related therewith. ${ }^{38}$ The

25 The 1992 Protocol to Amend the 1969 International Convention on Civil Liability for Oil Pollution Damage (CLC PROT 1992) (1956 UNTS 255; adopted: 27-11-1992; EIF: 30-05-1996) and the 1992 Protocol to Amend the 1971 International Convention on the Establishment of an International Fund for Compensation for Oil Pollution Damage (FUND PROT 1992) (1956 UNTS 330; adopted: 27-11-1992; EIF: 30-05-1996).

26 art V of CLC PROT 1992 and artV of Fund PROT 1992.

27 art II of CLC PROT 1992. The Convention applies to pollution damage in a Contracting State's territory, territorial waters and exclusive economic zone.

28 art 11(2) of CLC PROT 1992. The text of the Convention is available in IOPC Liability and Compensation for Oil Pollution Damage (2018) 5-19.

29 art 27(2) FUND PROT 1992. The text of the Convention is available in IOPC (n 28) 23-41.

30 art 2(1) of FUND 1992.

31 International Oil Pollution Compensation Funds (IOPC) "Explanatory Note” (2020) 1 https://iopcfunds.org/ wp-content/uploads/2020/09/explanatory-note_e.pdf (01-08-2020).

32 art 2(1)(a) FUND 1992.

33 IOPC (n 31) 1.

34 See IMO Status of IMO Treaties (2020) 288. See also art 2 of FUND PROT 1992.

35 IOPC (n 31) 1.

36 See IMO (n 34) 260-261.

37 long title. See also s 2(1) of the Act.

38 long title. See also s 2(1) of the Act. 
Contributions Act provides for the imposition of the International Oil Pollution Compensation Fund Contributions Levy ("the levy") on specific persons and sets out how the levy is determined and paid to the Fund. ${ }^{39}$ The Administration Act provides for administrative issues related to the levy imposed by the Contributions Act and connected matters. ${ }^{40}$

Prior to the enactment of the Civil Liability Act, the Marine Pollution (Control and Civil Liability) Act ("the Marine Pollution Act"), ${ }^{41}$ which was modelled partly on CLC 1969, was the only piece of legislation governing the liability of ship owners for ship-sourced oil pollution damage. The Civil Liability Act only removed from the Marine Pollution Act the provisions relating to liability covered by CLC 1992 or FUND 1992 or both. ${ }^{42}$ This means that "liability for bunker spills from non-tanker vessels [remains] covered by the [Marine Pollution] Act. Similarly, many administrative and intervention rights ... remain unaltered". ${ }^{43}$

In light of the economic and environmental threat posed by oil spills, it is vital that South Africa has adequate legislation in place to overcome the adverse effects of ship-sourced oil pollution damage. The domestic force given to CLC 1992 and FUND 1992 in South Africa is an important step in the right direction. This chapter examines the two conventions as they apply in South Africa as well as the domestic legislation which currently fills the gaps of their combined regime. Measures to enhance the existing liability and compensation regime for shipsourced oil pollution damage in South Africa are explored.

\footnotetext{
39 long title.

40 long title.

416 of 1981.

42 s 17 of the Civil Liability Act.

43 Hare Shipping Law \& Admiralty Jurisdiction in South Africa (2009) 566.
} 


\section{EVALUATION OF CLC 1992 AND FUND 1992 AS ENACTED INTO SOUTH AFRICAN LAW}

\section{Types of vessels and oil pollution covered by CLC 1992}

CLC 1992 defines the term "ship" narrowly as "any seagoing vessel and sea-borne craft of any type whatsoever constructed or adapted for the carriage of oil in bulk as cargo provided that a ship capable of carrying oil and other cargoes shall be regarded as a ship only when it is actually carrying oil in bulk as cargo and during any voyage following such carriage unless it is proved that is has no residues of such carriage in bulk aboard" ${ }^{44}$ CLC 1992 thus only applies to tanker vessels which are designed to carry oil in bulk and ore-bulk-oil carriers (OBOs), which are capable of carrying other cargo (dry cargo) and wet cargo such as oil. ${ }^{45}$ All other seaborne vessels, such as bulk carriers, container ships, general cargo ships, cruise ships and other vessels carrying passengers, tugs, dredgers, car carriers, fishing vessels, diving support vessels and drilling ships, are not covered by the Convention, even though these vessels often carry bunker oil fuel on board. ${ }^{46}$

The CLC 1992 definition of "oil" is limited to "any persistent hydrocarbon mineral oil such as crude oil, fuel oil, heavy diesel oil and lubricating oil, whether carried on board a ship as cargo or in the bunkers of such a ship". ${ }^{47}$ These persistent oils are composed of a considerable amount of heavy hydrocarbon fractions or high boiling material that does not disintegrate rapidly in the environment. ${ }^{48}$ These persistent oils present a threat to the environment and marine life, and remain in the environment long enough to necessitate responsive measures which may be costly. ${ }^{49}$ Compensation for responsive measures such as reasonable reinstatement

\footnotetext{
44 International Oil Pollution Compensation Funds (IOPC Funds) "Guidance for Member States Consideration of the Definition of 'ship"” (2016) 2 https://www.iopcfunds.org/uploads/tx_iopcpublications/IOPC_definition_of_ship_ ENGLISH_web.pdf (23-02-2019).

45 ibid.

46 ibid.

47 art I(5).

48 Anderson "Persistent vs non-persistent oils: What you need to know" Beacon (Skuld Newsletter) (2001) 1 https:// www.itopf.org/fileadmin/data/Documents/Papers/persistent.pdf (24-02-2019).

49 ibid.
} 
measures, including clean-up operations following persistent oil pollution spills, are covered by CLC 1992 and the Fund.

CLC 1992 does not cover non-persistent oils such as light diesel, gasoline and kerosene, composed of lighter hydrocarbon fractions which disintegrate rapidly through evaporation and seldom require responsive measures or only require limited responsive measures. ${ }^{50}$ However, although non-persistent oil dissipates rapidly through evaporation and rarely requires active responses, they nevertheless pose a threat, especially in high volumes, to private property and the environment. Indeed, non-persistent oils can impact paint coatings in marinas and harbours, causing damage to property. ${ }^{51}$ In addition, high concentrations in water are severely toxic to marine organisms, such as plants and animals. ${ }^{52}$ The death of marine organisms in turn impacts those who rely on marine life for their livelihood, such as commercial fishers, shrimpers and oystermen. It is thus important that liability and compensation be provided adequately not only in damage caused by persistent oil, but also in the case of damage caused by nonpersistent oil. As indicated earlier, liability and compensation for oil pollution damage caused by vessels other than oil tankers and/or non-persistent oil are regulated by the Marine Pollution Act, the adequacy of which will be examined in greater detail later. ${ }^{53}$

\section{Geographical application of CLC 1992}

CLC 1992 has a more extended geographical application than CLC 1969. The latter only applied to pollution damage within the States parties' land territories, internal waters and territorial seas. ${ }^{54}$ By contrast, CLC 1992 applies also in the exclusive economic zone (EEZ) or any equivalent area. ${ }^{55}$ The enactment of CLC 1992 thus provides for liability and compensation for damage occurring not only within South Africa's territory, including its internal and territorial waters,

50 ibid.

51 ibid.

52 ibid.

53 Act 6 of 1981.

54 art II.

55 art II. 
but also its EEZ. This ensures that liability and compensation exist not only for damage to the environment beyond the outer limit of the territorial sea up to the outer limit of the EEZ, but also for damage to the resources within that zone, over which South Africa has sovereign rights. ${ }^{56}$

\section{Strict liability}

According to CLC 1992, "the owner of a ship at the time of an incident, or, where the incident consists of a series of occurrences, at the time of the first such occurrence, shall be liable for any pollution damage caused by the ship as a result of the incident". ${ }^{57}$ CLC 1992 thus imposes strict liability for pollution damage on tanker owners, but provides for very limited cases in which they do not incur such liability. ${ }^{58}$ Strict liability is channelled exclusively to the ship owner, who is entitled to claim recourse from any contributing parties.$^{59}$ Claims against the servants or agents of the ship owner, a charterer, a "pilot or any person who, without being a member of the crew, performs services for the ship", a "manager or operator of the ship" or a salvor are expressly excluded unless "the damage resulted from their personal act or omission, committed with the intent to cause such damage, or recklessly and with knowledge that such damage would probably result". ${ }^{60}$ The benefit of channelling liability to the tanker owner is that victims of tanker oil pollution need not determine exactly who is liable in delict and can turn directly to the ship owner for compensation. ${ }^{61}$ Tracking down the exact party or parties at fault, and as such liable in delict, is often a time-consuming and costly process because a number of parties are usually involved in the navigation and management of a vessel. Another

56 See art 56(1)(a) of the 1982 United Nations Convention on the Law of the Sea (1833 UNTS 3, (1982) 21 ILM 1261; adopted: 10-12-1982; EIF: 16-11-1994; LOSC). See also s 7(2) of the Maritime Zones Act 1994 (15 of 1994$).$

57 art III(1).

58 In terms of art III(2), a tanker owner does not incur liability for oil pollution damage: (a) caused by an act of war, hostilities, civil war, insurrection or a natural phenomenon of an exceptional, inevitable or irresistible character; (b) caused wholly by an act or omission done with intent to cause damage by a third party; or (c) caused wholly by the negligence or other wrongful act of any Government or other authority responsible for the maintenance of lights or other navigational aids in the exercise of its function. In addition, art III(3) provides that, if the pollution damage was caused wholly or partly from an act or omission with intent to cause damage by the person who suffered the damage, or from the negligence of that person, the owner may be exonerated wholly or in part of liability to such person.

$59 \operatorname{IOPC}(\mathrm{n} 31) 3$.

60 art III(4).

61 Faure and Hui (n 24) 179188. 
benefit of channelling liability to the ship owner is that victims of oil pollution damage need not prove the extent of each contributing parties' liability, something which is difficult to do and often delays compensation. In addition, channelling liability to the owner prevents a duplication of the same claim, which could give rise to lengthy proceedings. ${ }^{62}$ While it has been submitted that, in the interest of promoting deterrence, third parties who have contributed to the loss should be exposed to liability, ${ }^{63}$ it should be noted that the CLC 1992's objective is only to ensure adequate and prompt compensation for victims of oil pollution damage, ${ }^{64}$ which strict liability channelled exclusively to the ship owner underpins.

\section{Financial limits on strict liability and compulsory insurance under CLC 1992}

Tanker owners are entitled to limit their liability to the financial limits set out in CLC $1992^{65}$ unless "it is proved that the pollution damage resulted from [their] personal act or omission, committed with the intent to cause such damage, or recklessly and with knowledge that such damage would probably result" ${ }^{66}$ The owner of a tanker carrying more than 2000 tonnes of oil as cargo must take out insurance or another financial security "to cover his liability for pollution damage under" the Convention ${ }^{67}$ and a certificate attesting that insurance or other financial security is in force must be carried on board the vessel. ${ }^{68}$ This means that the strict liability of the owner, although limited, is accompanied by an assurance of payment in the form of compulsory insurance. The assurance of payment is strengthened by provisions enabling the victim of oil pollution damage to take direct action against the insurer to obtain compensation. ${ }^{69}$ The compulsory insurance provisions ensure that finances, although capped, are available to compensate victims of oil pollution damage. By contrast, uncapped liability that is not accompanied by such a financial

\footnotetext{
62 Faure and Hui "International regimes for compensation of oil pollution: Are they effective" 2003 RECIEL 242250.

63 Faure and Hui (n 24) 188.

64 See the preamble to CLC PROT 1992.

$65 \operatorname{art} \mathrm{V}(1)$.

$66 \operatorname{art} \mathrm{V}(2)$.

67 art VII(1).

68 art VII(4).

69 art $\operatorname{VII}(8)$.
} 
guarantee might result in under compensation or no compensation at all when the ship owner is unable to pay. The combination of strict, but limited liability, with the assurance of payment provides the first tier of compensation for victims of oil pollution damage occurring in South Africa's land territory as well as its internal waters, territorial waters and EEZ.

\section{Compensation under Fund 1992}

The second tier is offered by the Fund set up in accordance with FUND 1992. ${ }^{70}$ The Fund compensates victims of tanker oil pollution damage where the ship owner is exempt from liability, unable to meet its financial obligations or the damage exceeds the financial caps on the ship owner's liability. ${ }^{71}$ The aggregate amount of compensation available under the Fund for a single incident is 203 million Special Drawing Rights ("SDR"), ${ }^{72}$ which includes the sum paid by the tanker owner (or its insurer) in accordance with CLC 1992. ${ }^{73}$ The Fund is financed by entities who receive more than 150000 tonnes of crude oil or heavy fuel oil (referred to as "contributing oil") a year at a port or terminal within a state party. ${ }^{74}$ The Fund relies on reports provided by States parties to determine which oil-receiving entities within the States are liable to pay the levy. ${ }^{75}$ The ten highest contributing States parties to the Fund (based on contributing oil received and reported to the Fund in 2018) are: India (14.59\%), Japan (12.10\%), the Republic of Korea (9.32\%), Italy (7.28\%), the Netherlands (7.19\%), Singapore (6.25\%), Spain (5.09\%), France (3.83\%), Thailand (3.40\%) and the United Kingdom (3.28\%). ${ }^{76}$ According to reports on contributing oil received and reported to the Fund

\footnotetext{
$70 \quad \operatorname{IOPC}(\mathrm{n} 31) 1$.

71 art 4(4)(a).

72 The SDR is a unit of account utilised by the International Monetary Fund (IMF). The value of the SDR is based on a basket of five national currencies namely the British pound sterling, the United States dollar, the Euro, the Japanese yen and the Chinese renminbi. The SDR is not a monetary system or claim against the IMF. It is a prospective claim on the freely utilisable currencies of IMF members. SDR can be changed for any of the basket currencies. See International Monetary Fund "Fact Sheet Explaining SDRs (Special Drawing Rights)" (2018) https://www.imf. org/en/About/Factsheets/Sheets/2016/08/01/14/51/Special-Drawing-Right-SDR (22-02-2019).

73 art $4(4)(a)$.

74 art 10(1) read with art 1(3).

75 IOPC (n 8) 28-29.

76 ibid 29.
} 
in 2018, South Africa received 20426819 tonnes of contributing oil, which amounted to $1.33 \%$ of the total amount. ${ }^{77}$

A problem faced by the Fund is that some States parties do not submit the necessary reports, ${ }^{78}$ with the result that the Fund is unable to levy contributions in respect of those States. ${ }^{79}$ In 2018, 15 States failed to meet their reporting obligation, while four States have outstanding reports for 5 years or more and 2 States have not submitted a single report since becoming States parties to the FUND $1992 .{ }^{80}$ The latter does not contain any provisions enabling the Fund to take action, such as withholding payment from the Fund, when a state fails to meet its reporting obligation. ${ }^{81}$ The Fund has nevertheless adopted the policy of assessing for admissibility, but withholding payments for claims from States that have 2 or more reports outstanding. ${ }^{82}$

Since South Africa became a party to FUND 1992, it benefits from the second tier of compensation offered to victims of tanker oil pollution damage. However, oil pollution incidents such as those related to the Erika ${ }^{83}$ and the Prestige ${ }^{84}$ have revealed that the aggregate amount available for compensation under CLC

77 ibid.

78 Jacobsson "The international liability and compensation regime for oil pollution damage from ships - International solutions for a global problem" 2007 Tul Mar LJ 1 7. States parties are obliged to submit reports in term of art 15(2) of FUND 1992 on the oil receiving entities and quantities received.

79 States parties in which there are no entities receiving an excess of 150000 tonnes of contributing oil for the year are still obliged to report a nil to the Fund's secretariat. In 2018, 43 States reported receiving no contributing oil within their territories. See IOPC (n 8) 28-29.

80 As at 31 December 2019, oil reports for the calendar year 2018 had not been received for the territories of 15 States parties. There are four States parties with outstanding reports for five or more years. Two States parties have not submitted any reports to the 1992 Fund since becoming Member States. IOPC (n 8) 29.

81 Jacobsson (n 78) 7.

82 IOPC “Annual Report” (2008) 38 https://www.iopcfunds.org/wp-content/uploads/2018/12/2008_ENGLISH_ ANNUAL_REPORT.pdf (24-07-2020). This policy was adopted by the Fund Assembly at its session in October 2008.

83 The Maltese-registered tanker broke in two off the coast of Brittany in France on 12 December 1999. The Erika was carrying a cargo of 31000 tonnes of heavy fuel oil, of which approximately 19800 tonnes were spilled. Around 400 kilometres of the coastline were affected by oil. Clean-up operations followed which quite swiftly removed most of the oil from the coastline. See IOPC "Incidents involving the IOPC Funds" (2013) 6 https://iopcfunds.org/ wp-content/uploads/2018/12/incidents2013_e.pdf (25-02-2019).

84 In 2002, the Bahamas-registered tanker carrying 76972 tonnes of heavy fuel oil started leaking oil off the coast of Galicia in Spain. While being towed away from the coast, the vessel broke in two and sank. Over the weeks that followed, oil continued to leak from the wreck at a declining rate. Approximately 63200 tonnes of heavy fuel oil were spilled and approximately 13700 tonnes of cargo remained in the wreck. The west coast of Galicia was severely contaminated by the oil, which eventually moved to affect the north coast of Spain and France. See IOPC (n 83) 12. 
1992 and FUND 1992 is sometimes inadequate to cover such large oil spills. ${ }^{85}$ In acknowledgement of that fact, a third tier of compensation was established in the form of an opt-in Supplementary Fund. The latter was introduced by the IMO through the Protocol of 2003 to FUND 1992 (FUND PROT 2003). ${ }^{86}$ The Supplementary Fund provides cover where the limits of the Fund are reached. ${ }^{87}$ FUND PROT 2003 provides a significant increase in the amounts available for compensation under CLC 1992 and FUND 1992 because the total aggregate amount available for compensation of a single tanker oil spill by the Supplementary Fund is 750 million SDR, which includes the amounts payable under CLC 1992 and FUND 1992. ${ }^{88}$

The annual contributions to the Supplementary Fund are levied in a similar manner as the contributions to the Fund because entities receiving more than 150000 tonnes of contributing oil per year within the States parties must also contribute to the Supplementary Fund. ${ }^{89}$ States parties are also obliged to submit reports providing information on the oil-receiving entities and the quantities of oil received to the Director of the Supplementary Fund..$^{90}$ The submission of information on oil receipts submitted in accordance with article 15 of FUND 1992 to the Director of the Fund is deemed to have been submitted also under FUND PROT 2003. ${ }^{91}$ The Supplementary Fund's contribution system differs, however, from that of the Fund in that contributions are based on a minimum presumed receipt of 1 million tonnes of contributing oil per year within a member state, even where no contributing oil is received or less than 1 million tonnes of contributing oil is received. ${ }^{92}$ This does not apply to South Africa in practice because, since FUND PROT 2003 came into effect, South Africa has reported

\footnotetext{
85 UNCTAD (n 1) 11.

86 Adopted: 16-05-2003; EIF: 03-03-2005. The text of the Protocol is available at https://www.iopcfunds.org/ fileadmin/IOPC_Upload/Downloads/English/WEB_IOPC_-_Text_of_Conventions_ENGLISH.pdf (20-012019). The Supplementary Fund was established in terms of art 2(1) of the Protocol.

87 art 4(1) of FUND PROT 2003.

88 art $4(2)(a)$.

89 art $10(1)$.

90 art 13(1).

91 ibid.

92 art 14(1)-(2).
} 
receiving well in excess of 10 million tonnes of contributing oil per year. ${ }^{93}$ South Africa, in any event, has not yet acceded to the Supplementary Fund. This also means that it cannot benefit from the third tier of compensation offered by the Supplementary Fund. ${ }^{94}$

As indicated above, the Supplementary Fund provides greater cover than that available under CLC 1992 and FUND 1992 and, as a result, it is less likely that the pollution damage caused by a single incident would exceed the Fund's limits of liability. ${ }^{95}$ Accession to FUND PROT 2003 would thus go a long way towards ensuring that the South African victims of a large oil spill are not without compensation or under-compensated.

\section{Pollution damage covered by CLC 1992 and FUND 1992}

\section{Environmental damage covered by CLC 1992 and FUND 1992}

The CLC 1992 definition of "pollution damage" is broad enough to cover "the costs of preventive measures and further loss or damage caused by preventive measures" 96 as well as compensation for the "impairment to the environment other than loss of profit from such impairment", but it limits that compensation to the "costs of reasonable measures of reinstatement actually undertaken or to be undertaken" to restore the environment to its pre-spill condition. " "Impairment to the environment" is not defined in CLC 1992, but it is understood to mean "an adverse alternation to the environment leading to the deterioration or weakening of its functioning". ${ }^{98}$ The term "reasonable measures" is not defined in CLC 1992, but it is understood to include reasonable measures to enhance the recovery process of the environment that do not cause further degradation and are proportionate,

93 See the International Oil Pollution Fund's annual reports from 2015 to 2018 https://iopcfunds.org/publications/ iopc-funds-publications/ (24-07-2020). In 2018, the South African oil industry received over 20 million tonnes of contributing oil. See IOPC (n 8) 28-29.

96 art 1(6)(b)

97 art 1(6)(a).

98 IOPC “Guidelines for presenting claims for environmental damage” (2018) 5 https://iopcfunds.org/wp-content/ uploads/2018/12/IOPC_Environmental_Guidelines_ENGLISH_2018_WEB_01.pdf (27-07-2020). 
feasible and connected to the spill. ${ }^{99}$ Compensation for post-spill studies with a sufficiently close link of causation to the spill are also covered. ${ }^{100}$

Extensive studies and past pollution incidents reveal that the marine environment is resilient enough to recover without any intervention because oil spills rarely impact the marine environment permanently. ${ }^{101}$ For that reason, CLC 1992 does not make provision for the compensation of environmental damage in and of itself, that is pure environmental damage based on abstract quantification, calculated in accordance with theoretical models is not provided. ${ }^{102}$ The Fund has thus rejected abstract quantifications, for instance, in the Volgoneft incident ${ }^{103}$ when a "Methodika" claim, the amount of which was calculated by multiplying the quantity of oil spilled by a number of roubles per tonne, had been submitted by Russia. ${ }^{104}$ The Fund's rejection of the claim was affirmed by the Arbitration Court of Saint Petersburg and Leningrad Region in September 2010 on the basis that compensation for "impairment to the environment" under article 1(6) of CLC 1992 is restricted to the costs of reasonable reinstatement measures. ${ }^{105}$

Although France, like Russia, is a member of CLC 1992, the French Criminal Court of First Instance in Paris awarded compensation for pure environmental damage resulting from the Erika incident. ${ }^{106}$ The award included moral damages (including loss of enjoyment), damage to reputation and the brand image of several regions and municipalities as well as moral damages resulting from damage to natural heritage. ${ }^{107}$ The Criminal Court in Paris recognised the right of an environmental association, with special powers for the protection, management and conservation

99 IOPC “Claims Manual” (2019) 39-40 https://iopcfunds.org/wp-content/uploads/2018/12/2019-ClaimsManual_e-1.pdf (27-07-2020).

100 IOPC (n 98) 15.

101 ibid 39.

102 IOPC (n 99) 14.

103 On 11 November 2007, the Russian-registered tanker Volgoneft broke in two in the Strait of Kerch linking the Sea of Azov and the Black Sea between the Russian Federation and Ukraine. While at anchor, the tanker got caught in a severe storm and heavy seas. The tanker was carrying 4077 tonnes of heavy fuel oil almost half of which spilled into the sea.Approximately 250 kilometres of the coastlines of the Russian Federation and Ukraine were affected by the oil. More than 30000 birds reportedly died. See IOPC (n 83) 25-26.

104 ibid.

105 ibid.

106 ibid 8.

107 ibid. 
of an area, to claim compensation for moral and environmental damage to the area it is tasked with safeguarding. ${ }^{108}$ At the Fund's Executive Committee's $40^{\text {th }}$ session, in March 2008, numerous delegates expressed concern that the Criminal Court had awarded compensation for pure environmental damage although CLC 1992 restricts compensation for the environment to reasonable reinstatement measures. ${ }^{109}$ Several delegations stated that the decision could have significant impacts for the CLC 1992 and Fund regime. ${ }^{110}$ At that point in time, however, the Fund was unable to ascertain the impact of the decision since it was pending appeal. ${ }^{111} \mathrm{In}$ March 2010, the decision of the Criminal Court in Paris was affirmed on appeal by the French Court of Appeal in Paris. ${ }^{112}$ In delivering its judgement the French Court of Appeal appeared to have little regard for the Fund's interpretation of Article 1(6) of CLC 1992, but instead controversially held that the provision does not rule out compensation for pure environmental damage. ${ }^{113}$ When requested not to channel strict liability on the basis that the latter decision was founded on national law and not the CLC 1992 and Fund regime the court rejected such possibility, emphasising that Article 1(6) does not preclude compensation for pure environmental damage. ${ }^{114}$ The award of pure environmental and moral damages was further affirmed by the French Court of Cassation (the highest court in the French Judiciary) in March 2010. ${ }^{115}$ The French courts acknowledged and quantified compensation for pure environmental damage even though such compensation is not permitted under CLC 1992 and the Fund as affirmed in the IOPC Fund's Claims Manual.

The Fund Committee has noted that the judgment of the French Court of Cassation is not binding on the Fund because the Fund was not party to

108 ibid.

109 IOPC (n 82) 81.

110 ibid.

111 ibid.

112 IOPC (n 83) 8-9.

113 Kopela "Civil and criminal liability as mechanisms for the prevention of oil marine pollution" 2011 RECIEL 313320.

114 ibid.

115 IOPC (n 83) 10. 
the criminal proceedings. ${ }^{116}$ Nonetheless the French courts' interpretation and application of CLC 1992 is contentious. ${ }^{117}$ They highlight that the CLC 1992 is reliant on its interpretation and application within national jurisdictions. ${ }^{118}$ The uniform interpretation and application of CLC 1992 is an important factor of the regime's success. ${ }^{119}$ While awarding compensation for pure environmental damage is in line with developments in environmental law and the polluter-pays principle and may also have a deterring effect on future spills and substandard shipping in the oil industry, ${ }^{120}$ varying interpretations of CLC 1992 might derail the international regime created by CLC 1992 and FUND 1992. ${ }^{121}$ Indeed, admitting claims for pure environmental damage which are not covered by CLC 1992 may widen the ambit of liability of the Fund further than intended, something which may impact its viability. ${ }^{122}$ Furthermore, the aim of CLC 1992 and the Fund regime is only to provide adequate and prompt compensation for oil pollution damage rather than to address deterrence and sub-standard shipping. ${ }^{123}$ The French courts' decisions pose questions as to whether the objectives of CLC 1992 should be reevaluated as far as substandard shipping is concerned. ${ }^{124}$ In addition, the decisions also illustrate the views expressed by France in support of extending compensation under CLC 1992 for pure environmental damage. ${ }^{125}$ While States parties have expressed concerns about substandard shipping and some delegations supported

116 IOPC “Annual Report” (2013) 31 https://iopcfunds.org/wp-content/uploads/2018/12/annualreport2013_e.pdf (01-09-2020).

117 Kopela (n 113) 323.

118 ibid.

119 ibid. See also IOPC (n 82) 48. Assemblies of the Funds have expressed the view that a uniform definition of "pollution damage" is essential for the CLC 1992 and the Fund regime.

120 Kopela (n 113) 323.

121 ibid.

122 See Jacobsson (n 78) 24, who notes that it is important for the future viability of the CLC 1992 and Fund regime that States parties adhere to the Fund's policies.

123 Kopela (n 113) 323.

124 ibid.

125 ibid. See also the 2000 submission by the French delegation (Review of the International Compensation Regime Third Intersessional Working Group (Doc. 92FUND/WGR.3/2/1 28 June 2000) par 2.2) where France expressed the view that there is a trend in the national legislation of some States to award more than "mere reinstatement measures" based on the influence of public perceptions and increased environmental awareness; and the 2001 submission by the French delegation (Review of the International Compensation Regime Third Intersessional Working Group (Doc. 92FUND/WGR.3/5/6 08 March 2001) par 4) where the delegation pointed out that international environmental law is slowly extending the boundaries of damage covered in respect of "related interests", including "amenity values". 
using the civil liability regime as a measure of deterrence, others have opposed such an extension in light of the regime's objectives. ${ }^{126}$ The European Commission has also suggested that the civil liability regime be amended to contribute to the deterrence of sub-standard shipping in the oil industry. ${ }^{127}$ In future, the courts of States parties may thus, in the interest of increased global environmental awareness, the protection of environmental rights, the deterrence of substandard shipping and the prevention of oil spills, be more inclined to hold the polluter liable for pure environmental damage. This may result in other States parties of the Fund taking the same stance as France to award pure environmental damage even though the Fund has noted that it is not bound by the Erika decision.

In Spain, in relation to the Prestige oil spill, the Spanish Criminal Court in Corcubión awarded around $€ 1241$ million for pure economic loss. ${ }^{128}$ On appeal, on 20 December 2018, the Spanish Supreme Court held, however, that the Fund does not incur liability to compensate victims for pure environmental and moral damage because article 1(6) of CLC 1992 excludes such damages and only covers reasonable reinstatement measures. ${ }^{129}$

In South Africa, the polluter-pays principle is entrenched in domestic environmental legislation. Section $2(4)(p)$ of the National Environmental Management Act (NEMA) ${ }^{130}$ obliges the polluter to pay the costs of remedying the effects of pollution as well as preventing, minimising or controlling further pollution. ${ }^{131}$ Section 28 of NEMA places a duty on the polluter to take "reasonable measures", ${ }^{132}$ which include measures to:

“(a) investigate, assess and evaluate the impact on the environment;

126 Kopela (n 113) 323. See also Report on the Ninth Meeting of the Third Intersessional Working Group (Doc 92FUND/A10/7 10 May 2005) par 7.1,7.5 and 7.7.

127 Kopela (n 113) 323. See also Directive 2004/35/CE of the European Parliament and of the Council of 21 April 2004 on environmental liability with regard to the prevention and remedying of environmental damage Official Journal L 143/56 of 30 April 2004 0056-0075.

128 IOPC (n 83) 16.

129 Cassation appeal/606/2018 23-25 https://iopcfunds.org/incidents/incident-map\#1916-13-November-2002 (3008-2020). See further IOPC "Recent developments in the Prestige incident - December 2018 Judgment" (2019) https://iopcfunds.org/news/recent-developments-in-the-prestige-incident-december-2018-judgment/ (30-082020).

130107 of 1998.

131 s $2(4)(\mathrm{p})$.

132 s $28(1)$. 
(b) inform and educate employees about the environmental risks of their work and the manner in which their tasks must be performed in order to avoid causing significant pollution or degradation of the environment;

(c) cease, modify or control any act, activity or process causing the pollution or degradation;

(d) contain or prevent the movement of pollutants or the causant of degradation;

(e) eliminate any source of the pollution or degradation; or

(f) remedy the effects of the pollution or degradation". ${ }^{133}$

Section 30A of NEMA applies to "emergency situations"134 such as oil spills and requires the person who caused the emergency situation to take measures to mitigate, prevent, control and rehabilitate the impact thereof on the environment. ${ }^{135}$ These legislative measures do not appear to extend to compensation for pure environmental damage, but they hold the polluter financially liable for reasonable measures to prevent, minimise, rectify and control the effects of oil pollution damage. This is aligned to CLC 1992, as interpreted in the Fund's Claims Manual, which limits compensation for the impairment of the environment to "reasonable reinstatement measures".

Section 24 of the Constitution of the Republic of South Africa, 1996, grants everyone a right "to an environment that is not harmful to their health or wellbeing" and to have their environment protected by the State through reasonable legislative and other measures that prevent pollution and ecological degradation, promote conservation and secure ecologically sustainable development". This right is supported by the locus standi clause in the Constitution, "granting anyone acting in the public interest" the right to challenge any violation of the environmental right before a court. ${ }^{136}$ The concept of "health" relates to human health, which

133 s $28(3)$.

134 s 30A (7) defines an "emergency situation" as "a situation that arises suddenly and poses an imminent and serious threat to the environment, human life, property, including a disaster". This definition is broad enough to include an oil spill.

135 s $30 \mathrm{~A}(3)$.

136 See s 38(d) of the Constitution. See also Witbooi "Restrictive environmental measures: (When) do they justify compensation for the property owner"2001 SAJELP 215231. 
includes both mental and physical health. ${ }^{137}$ While "well-being" could be broadly interpreted so as to include spiritual or psychological characteristics including an individual's need to be able to connect with nature, ${ }^{138}$ to do so would bring environmental issues, such as conservation and the maintenance of biodiversity, within the ambit of the environmental right enshrined in the Constitution. ${ }^{139}$ Such a broad interpretation could also be the basis upon which compensation for pure environmental damage is awarded in South Africa. The South African courts have, however, been hesitant to broadly interpret "well-being" to include aesthetic or spiritual dimensions and have limited it to physical discomfort. ${ }^{140}$ The South African courts have thus not granted compensation for pure environmental damage and have limited compensation for the impairment of the environment to measures to prevent, rectify, minimise and control pollution. However, the possibility of the South African courts awarding compensation for pure environmental damage cannot be permanently excluded because increased global environmental awareness, the need to deter substandard shipping and the prevention of oil spills may lead to the courts more broadly interpreting the concept of "well-being" so as to accommodate compensation for pure environmental damage.

\section{Pure economic loss}

The CLC 1992 definition of "oil pollution damage" is broad enough to encompass loss of profits, including such losses sustained as a result of the "impairment of the environment". ${ }^{141}$ The Convention however does not specify which such losses are covered. There is a broad range of profit losses which can be sustained following an oil spill. A person or entity may suffer loss of profits as a result of damage to his, her or its private property. For example, a fisher whose nets have been contaminated by the spill may suffer a loss of profit for the time period

137 Warnich “Environmental Right in Terms of the Constitution” (2018) https://www.polity.org.za/article/ environmental-right-in-terms-of-the-constitution-2018-02-14 (25-07-2020).

138 ibid. See also Witbooi (n 136) 233.

139 Warnich (n 137).

140 ibid. See also Hichange Investments v Cape Produce Co (Pty) Ltd t/a Pelts Products 20042 SA 393 (E).

141 art 1(6) of CLC 1992. 
that the fishing nets are being cleaned, repaired or replaced. ${ }^{142}$ This type of loss of profits, which is linked to property damage, is known as a "consequential loss". ${ }^{143}$ Other parties or entities may suffer a loss of profits without sustaining any loss or damage to private property; such losses may arise solely from the "impairment of the environment" upon which they rely for their livelihood or business. ${ }^{144}$ These losses are known as pure economic losses and such losses can be quite widespread following a damaging spill. ${ }^{145}$ Indeed, oil spills often severely impact the marine environment, marine organisms and the coastline, upon which many parties rely directly for their livelihood and business such as commercial fishers, fish farms, restaurants, hotels and campsites on the coastline. ${ }^{146} \mathrm{~A}$ fisher might, for example, sustain pure economic losses following an oil spill due to reduced fishing stocks (due to mortalities or contamination), interruption of fishing activities, a loss of market or reduced sale prices. ${ }^{147}$ As far as it is concerned, the tourism industry might face a loss of income due to a reduction in tourists as a result of the spill and may incur additional costs of promotion. ${ }^{148}$ Secondary or indirect pure economic losses can also be sustained by other industries that rely on the directly affected industries. ${ }^{149}$ For example, the industries providing fuel, ice and nets as well as fish wholesalers and retailers who depend on the fishing industry may suffer a decline in business and profits where fishing and fishing business decrease. ${ }^{150}$ Likewise, the industries providing goods and services to the tourism industry might incur losses if the tourist industry takes a dip because the number of tourists visiting the contaminated area decline. ${ }^{151}$

142 IOPC (n 99) 14.

143 ibid.

144 ibid.

145 ibid. See also Palmer "The great spill in the Gulf...and a sea of pure economic loss: Reflections on the boundaries of civil liability” 2011 Penn State Law Review 105110.

146 IOPC (n 99) 32 and 36.

147 For a full discussion of losses in the fishing industry, see IOPC "Guidelines for presenting claims in the fisheries, mariculture and fish processing sector” (2019) https://iopcfunds.org/wp-content/uploads/2017/04/2019_ Fisheries_e.pdf (27-07-2020).

148 For a full discussion of losses in the tourism industry, see IOPC "Guidelines for presenting claims in the tourism sector” (2018) https://iopcfunds.org/wp-content/uploads/2018/08/IOPC-Tourism-Guidelines_ENGLISH-2018WEB.pdf (27-07-2020).

149 IOPC (n 99) 32 and 37.

150 ibid 32.

151 ibid 14 and 37. 
The decision as to which of the above-discussed claims for pure economic loss are admissible for compensation is left largely to the courts of the States parties. While the admissibility of claims for consequential economic loss is not controversial and is affirmed by the Fund in its Claims Manual, claims for pure economic loss are more problematic. ${ }^{152}$ In order to assist the domestic courts in determining where the cut-off line should be drawn in respect of claims for loss of profits, the Fund provides guidelines in its Claims Manual. The latter sets out that claims for pure economic loss by the tourism sector and those relating to fisheries and mariculture activities will only be admissible for compensation where there is "a sufficiently close link of causation" between the contamination and the loss claimed. ${ }^{153}$ In determining whether such a "sufficiently close link of causation exists", the Fund looks at: (1) the geographic proximity of the claimant's business activity to the contaminated area; (2) the degree to which the claimant's business is financially reliant on the impacted resource (such as the polluted area of the sea); (3) the extent to which the claimant had other sources of supply or alternative markets; and (4) the extent to which the claimant's business forms an integral part of the economic activity within the contaminated area. ${ }^{154}$ When applying those criteria, the Fund has accepted claims for pure economic loss from those directly reliant on the impaired environment such as those involved in mariculture, fishing and shellfish gathering, fish processors/vendors, fishers as well as beachfront restaurants, campsites and hotels that suffered a loss of income due to a decline in tourism activities. ${ }^{155}$ At the same time, the Fund has rejected claims of a more secondary and indirect nature for lacking a sufficient link of causation. Examples are the claims of a food merchant selling frozen food to restaurants, a salt-producer who suffered loss due to a self-imposed quota rather than the spill, a fish wholesaler whose business was located outside the contaminated region and a subrogated claim from a hotel insurer for the cancellation of a millennium party due to a storm and not the spill. ${ }^{156}$

152 ibid 14: "Under certain circumstances, claims for pure economic loss are payable".

153 ibid 15.

154 ibid 32-33 and 36-37.

155 IOPC (n 82) 84-87.

156 ibid. 
The Fund's criteria are not binding on the courts of States parties, ${ }^{157}$ but they should be taken into account when interpreting the provisions of CLC 1992, according to article 31(3)(b) of the 1969 Vienna Convention on the Law of Treaties. ${ }^{158}$ The Fund's criteria are quite general and flexible to make accommodation for new and existing claims as they are applied to assess each case on its own merits. ${ }^{159}$ The criteria are also "pragmatic" and accommodate the financial climate, geographic location and political influences which may influence the admissibility of claims for pure economic loss. ${ }^{160}$ Therefore, even where a court considers the Fund's criteria or makes reference to them, it retains a large degree of flexibility in determining which claims for pure economic loss are admissible. ${ }^{161}$ In addition, this inherent flexibility in the criteria leaves room for the legal background of a state party and its approach to claims for economic loss to influence its courts' interpretation of the criteria. As a result, the courts in one state party might interpret the Fund's criteria narrowly, while the courts in another state might interpret the criteria more broadly to admit a greater range of claims for pure economic loss. The inherent flexibility built into the Fund's criteria makes this possible and may in itself threaten uniformity.

In the United Kingdom, the courts are very restrictive in their approach to claims for pure economic loss, which were traditionally precluded in the absence of property damage by the "economic loss rule", but have made an exception to accept claims for loss of profit by fishermen directly reliant on the contaminated area even in the absence of property damage. ${ }^{162}$ The restrictive approach of the courts in the United Kingdom was evident following the grounding of the

157 ibid 49. See also Jacobsson (n 78) 27.

1581155 UNTS 331, (1969) 8 ILM 679. Adopted: 23-05-1969; EIF: 27-01-1980: “There shall be taken into account, together with the context: ... (b) any subsequent practice in the application of the treaty which establishes the agreement of the parties regarding its interpretation".

159 IOPC (n 82) at 87.

160 Soyer "Ship-sourced oil pollution and pure economic loss: The quest for overarching principles" 2009 Torts LJ 16. 161 ibid.

162 Huang Recoverability of Pure Economic Loss Arising from Ship-Source Oil Pollution (2011) 254. 
$B R A E R^{163}$ in Scotland and the Sea Empress ${ }^{164}$ in Wales where the courts in these jurisdictions had to grapple with the admissibility of claims for pure economic loss. The courts applied the criteria of proximity (both physical and causal) between the contamination and the loss. ${ }^{165}$ On that basis, a claim for loss of profits by a smolt producer (Landcatch Ltd), located $500 \mathrm{~km}$ from the contaminated region, was denied because the loss was caused by customers' unwillingness to purchase smolt after the spill, rather than by the contamination itself. ${ }^{166}$ Likewise, a claim for loss of income (due to a decline in passengers) by the main ferry operator from the Shetland Islands to the mainland was denied on the basis that the loss was not a direct consequence of the spill, but rather an indirect result, caused by negative publicity affecting the image of the Shetland area as a holiday destination. ${ }^{167}$ After the Sea Empress ran aground, a fish processing company located out of the contaminated area, Tilbury, claimed loss of profits following a fishing ban in the contaminated area. Tilbury alleged that it lost $£ 643557$ in profits that it would have made from processing whelks obtained from fishers fishing in the contaminated area and selling them to the Korean market. Tilbury's claim was denied due to a lack of proximity, rendering the claim too remote, "secondary" and "indirect". ${ }^{168}$ On appeal, the court emphasised that the term "damage" was restricted to physical contamination and its consequences and that Tilbury's loss

163 In January 1993, having experienced an engine failure, the oil tanker BRAER ran aground, amidst severe weather conditions in the Shetland Islands area. The tanker was carrying about 85000 tonnes of oil, almost all of which spilled into the surrounding waters. The oiling of the coastline was relatively minimal in comparison to the scale of the spill and clean-up operations were limited, but many birds and mammals died and a wide range of fish and shellfish over a fairly large area became contaminated with oil. The latter resulted in the implementation of a fishing ban in the contaminated region and millions of farmed salmon (more than $25 \%$ of the total production for the Shetlands that year) could not be sold and had to be destroyed. See Goodlad "Effects of the Braer oil spill on the Shetland seafood industry" 1996

The Science of the Total Environment 127 127-128 and 130.

164 In February 1996, the oil tanker Sea Empress ran aground in the entrance to Milford Haven in the South-West of Wales and around 72000 tonnes of light crude oil and 480 tonnes of heavy fuel oil were released into the surrounding waters contaminating approximately $200 \mathrm{~km}$ of the Pembrokeshire coastline, much of which is part of a national park, is well known for its natural beauty and is used for a variety of purposes including tourism, fisheries and mariculture. See Nikitik, Andrew and Robinson "Patterns in benthic populations in the Milford Haven waterway following the Sea Empress oil spill with special reference to amphipods" 2003 Marine Pollution Bulletin 11251125.

165 Soyer (n 160) 14.

166 Landcatch Ltd v International Oil Pollution Compensation Fund [1999] 2 Lloyd's Rep 316, affirming the decision of Lord Gill in Landcatch Limited v Braer Corporation and Another [1998] 2 Lloyd's Rep 552.

167 Skerries Salmon Ltd v The Braer Corporation [1999] SLT 1196.

168 ibid. 
resulted instead from its inability to process whelks at a location far away from the contaminated regions. ${ }^{169}$ All the aforementioned decisions are consistent with the Fund's criteria in rejecting claims of a secondary and indirect nature, being without a sufficiently close link to the contamination. That approach appears to be premised on the general inadmissibility of claims for pure economic loss, with the exception of claims by those directly reliant on the affected resource. ${ }^{170}$

In China, claims for pure economic loss have not garnered much attention from the courts. ${ }^{171}$ The Tasman Sea oil spill was the first public case where commercial fishers directly dependent on the affected environment were granted compensation for economic loss due to the disruption in fishing and harvesting activities caused by the spill. ${ }^{172}$ In that case, directness rather than the Fund's criteria was used to determine the scope of admissibility of the claims for pure economic loss. It remains to seen whether the Chinese courts will admit claims for pure economic loss that have a close causal link to the contamination, but are not directly caused by it.

In French law, there is no rule precluding claims for pure economic loss. ${ }^{173}$ A claim for negligently inflicted pure economic loss is not likely to face many technical burdens and the French courts are quite open to finding in favour of the plaintiffs in tort. ${ }^{174}$ To limit the claims admissible for pure economic loss, the French courts have required a link of causation and applied the requirements of foreseeability and directness. ${ }^{175}$ Following the Erika oil spill, some French courts relied on the Fund's criteria to admit claims for pure economic loss while others did not, emphasising that the Fund's criteria are not binding on the courts. ${ }^{176}$ In most instances, the French courts reached the same decisions as the Fund

169 R J Tilbury \& Sons (Devon) Ltd (t/a East Devon Shellfish) v Alegrete Shipping Co Inc [2003] 2 All ER (Comm) 1, [2003] 1 Lloyd's Rep 327, [2003] 1 CLC 325.

170 Jacobsson (n 78) 27.

171 Huang (n 162) 262.

172 ibid.

173 Huang (n 162) 255.

174 ibid 256.

175 ibid.

176 Jacobsson (n 78) 28. 
would have reached and, where they differed, they were overturned on appeal and brought in line with the decisions of the Fund. ${ }^{177}$

In South Africa, the courts are cautious to grant claims for pure economic loss where doing so would lead to indeterminate liability. ${ }^{178}$ Under Roman-Dutch law, claims for pure economic loss without related loss or damage to property were precluded. ${ }^{179}$ Although the courts have been cautious to extend delictual liability to claims for pure economic loss, such claims may be successful where the elements of a delict are met. ${ }^{180}$ This means that wrongfulness needs to be established, something which ordinarily requires establishing whether a legal duty exists. ${ }^{181}$ In South Africa, no general duty exists in respect of negligently inflicted pure economic loss. As a result, each court will have to decide, on a case-bycase basis, whether a duty exists. ${ }^{182}$ That decision is likely to be made taking into account the boni mores ${ }^{183}$ the environmental right entrenched in the Constitution as well as environmental legislation and societal environmental awareness. There has not been any case in South Africa dealing with claims for pure economic loss caused by an oil spill yet ${ }^{184}$ and it remains to be seen to which extent such claims will be accepted by the courts.

It appears that, in most instances, the courts in the States parties have admitted claims for pure economic loss that align with the Fund's criteria, although reference has not always been made to the criteria. In a number of States parties, case law in respect of claims for pure economic loss still appears to be developing and it is unclear whether such development will lead to claims for pure economic loss being narrowly admitted, to prevent indeterminate liability and a multitude of claims, or more broadly admitted in light of social and political considerations. In the absence of a uniform approach, the outcome of a claim for pure economic

177 ibid.

178 Kotze "Interpretation of claims for pure economic loss under art 1(6)(c) of the Hazardous and Noxious Substances Convention" 2002 SAYIL 171 178-179.

179 ibid 177.

180 ibid.

181 ibid.

182 ibid 177-178.

183 ibid 178.

184 ibid 180. 
loss following an oil spill remains largely uncertain and dependent on where the incident takes place and where the claim is subsequently instituted. A very broad interpretation of the Fund's criteria leading to a broad admissibility of claims for pure economic loss should be cautioned against in order to avoid unwarranted costs (for losses that are too remote) being incurred with the risk of endangering the Fund's viability. ${ }^{185}$ At the same time, one should avoid an overly restrictive approach, which might preclude genuine claims for pure economic losses linked to the contamination.

In instances of very large-scale spills, it is particularly hard for the domestic courts to decide exactly where to draw the line between admissible and inadmissible claims for pure economic loss because of the broad range of potential victims and the far-reaching effects of the oil spill. An example is the Deepwater Horizon incident in April 2010. In this case, the platform exploded while in use at the Macondo Prospect (a seabed location) approximately 40 miles from the southeast coast of Louisiana, releasing some 4.9 million barrels of oil and becoming the largest marine oil spill in United States ${ }^{186}$ contaminating the marine environment and shore along the Gulf Coast and causing multibillion losses in the fisheries sector and tourist industry. ${ }^{187}$ Many beaches and marshes in a number of Gulf regions were impacted by the blowout, beachfront hotels and their employees were impacted by a decline in hotel reservations, real-estate agents selling and renting properties on the Gulf Coast were affected by a decline in property values in the region, drillers were precluded from drilling by a federal moratorium on deepwater drilling, and commercial fishers as well as those reliant on fish and other seafood from the Gulf waters, such as seafood restaurants, fish markets, wholesalers and grocery stores, suffered a decline in business. ${ }^{188}$ Unsurprisingly, the majority of

185 Davis "Pure economic loss claims under the Oil Pollution Act: Combining policy and congressional intent" 2011 Colum JL \& Soc Probs 1 44, who states that unwarranted costs can flow from a more liberal interpretation of provisions relating to pure economic loss (in the case of the United States Oil Pollution Act, 1990); Jacobsson (n 78) 24, who notes that it is important for the future viability of CLC 1992 and the Fund regime that States parties adhere to the Fund's policies.

186 Selby "In re: Oil Spill by the Oil Rig Deepwater Horizon on the Gulf of Mexico, on April 20, 2010, Order, Aug 26, 2011” 2012 Harv Env LR 533 533; Perry “The Deepwater Horizon oil spill and the limit of civil liability" 2011 Wash LR 11.

187 Perry (n 186) 2.

188 Davies "Deepwater Horizon: Removal costs, civil damages, crimes, civil penalties and State remedies in oil spill cases” 2011 Tul LR 124. 
the claims resulting from the incident were for pure economic loss. ${ }^{189}$ In fact, the potential liability following a spill of this magnitude is endless because everyone who suffers some sort of setback as a result of the spill influences the business of another. ${ }^{190}$

The United States of America are not a party to CLC 1992 and FUND 1992. The applicable federal legislation is the Oil Pollution Act (OPA) of $1990,{ }^{191}$ enacted in response to the Exxon Valdez spill. ${ }^{192}$ Until then, claims for pure economic loss were precluded under general maritime law by the Robins Dry Dock rule, which only permitted claims for economic loss linked to loss or damage to property. ${ }^{193}$ By contrast, the OPA expressly permits a claimant to recover economic loss, even in the absence of any damage to the claimant's property. Under section 2702(b) (2)(E) of the OPA, "loss of profits or impairment of earning capacity due to the injury, destruction, loss of real property, personal property, or natural resources" can be recovered by "any claimant". ${ }^{194}$ The exact causal nexus required by the phrase "due to" is however not set out in the OPA. ${ }^{195}$ There are very few judicial decisions clarifying the scope of that provision and the causal link required by the words "due to" has been the subject of varying interpretations, which have vacillated from requiring the oil pollution damage to be sole cause or proximate cause of the loss, on the one hand, to a contributing cause of the loss, on the other. ${ }^{196}$ In an unreported decision of the United States District Court for the Eastern District of Louisiana, a proximate cause test was applied to establish which

189 BDO Consulting “Independent Evaluation of the Gulf Coast Claims Facility Report of Findings \& Observations to the U.S. Department of Justice” (2012) 60 https://www.justice.gov/iso/opa/resources/66520126611210351178.pdf (10-08-2020).

190 Palmer (n 145) 110.

191 Pub L No 101-380, Aug 18, 1990, 104 Stat.

192 In March 1989, the oil tanker Exxon Valdez ran aground in Prince William Sound, Alaska, and spilled an estimated 42 million litres of crude oil. The oil subsequently spread over more than $26000 \mathrm{~km} 2$ of water in other parts of the Gulf of Alaska contaminating over $1000 \mathrm{~km}$ of the coastline. The spill resulted in high mortalities of seabirds and other marine mammals, hundreds of thousands of seabirds, several thousand sea otters and a significant proportion of killer whales. Other wildlife species were also impacted. See Eslera, Ballacheya, Matkinb, Cushingc, Kalerd, Bodkina, Monsona, Esslingera and Kloeckera "Timelines and mechanisms of wildlife population recovery following the Exxon Valdez oil spill” 2018 Deep-Sea Research Part II:Topical Studies in Oceanography 3636

193 Robins Dry Dock \& Repair Co v Flint 275 US 303 (1927).

19433 US Code $\$ 2702$.

195 Davis (n 185) 21.

196 Davies "Liability issues raised by the Deepwater Horizon blowout" 2011 A\&NZ Mar LJ 3538. 
claims for pure economic loss were admissible according to section 2702(b)(2) (E) ${ }^{197}$ In terms of that test, claims for economic loss by those who rely directly on the affected natural resource, such as fishers, are admissible while claims by those indirectly reliant on the resource, such as seafood restaurants, are not. ${ }^{198}$

After the Deepwater Horizon spill, British Petroleum (BP) set up a Gulf Coast Claims Facility (GCCF) that aimed to fully compensate victims who suffered oil pollution damage as a result of the spill. ${ }^{199}$ The GCCF was backed by a $\$ 20$ billion trust fund accompanied by an open-ended commitment in the event that the amount proved insufficient. ${ }^{200}$ The GCCF sought to resolve private claims (from individuals and businesses) against BP resulting from the spill outside the court system in an expeditious manner. ${ }^{201}$ The GCCF made emergency payments, for which claimants were not required to sign a release and final settlements. ${ }^{202}$ By contrast, claimants who accepted final payment from the GCCF had to sign an undertaking not to pursue action against $\mathrm{BP}$ in court. ${ }^{203}$ In admitting claims for pure economic loss flowing from the spill, the GCCF applied a proximate cause test, requiring claimants to show that the spill was the proximate cause of their loss. ${ }^{204}$ In practice, the GCCF liberally applied the proximate cause test and granted cover not only to those directly reliant on the Gulf's resources and within its immediate vicinity but also to those who were physically unaffected by the oil spill but suffered a decline in business due to a decrease in tourists. ${ }^{205} \mathrm{In}$ fact, in its Final Payment Methodology the GCCF indicated that neither physical proximity to the spill nor a particular type of work or industry is a precondition

\section{7 ibid.}

198 ibid.

199 Issacharoff and Rave "The BP oil spill settlement and the paradox of public litigation" 2014 Loyola LR 398398. 200 ibid.

201 ibid 400.

202 ibid 421.

203 ibid 420-421; BDO Consulting (n 189) 29.

204 BDO Consulting (n 189) 38. See also Gulf Coast Claims Facility (GCCF) "Protocol for Emergency Advance Payments" (2010) 5 https://www.restorethegulf.gov/sites/default/files/imported_pdfs/library/assets/gccfemergency-advance-payments.pdf. (07-08-2020), which indicated that the GCCF would apply a "proximate cause test" and claimants would have to demonstrate geographic proximity, describe the nature of the industry and explain their reliance on the natural resources in order to successfully claim for pure economic loss resulting from the Deepwater Horizon incident.

205 Davis (n 185) 31. 
for compensation, although the latter played a role in the type of proof needed to substantiate a claim. ${ }^{206}$ By the end of 2011, the GCCF had processed more than 1 million claims and paid out over $\$ 6.2$ billion to individuals and businesses. ${ }^{207}$ Approximately $99.8 \%$ of the claims and $99.6 \%$ of the amounts paid by the GCCF related to claims for pure economic loss. ${ }^{208}$ Although the majority of the payments for compensation $(74 \%)$ were made to claimants in the immediate vicinity, a sizeable portion of the amount paid for compensation went to businesses in regions which were physically unaffected by the spill. ${ }^{209}$

Many individuals and entities impacted by the spill questioned the decisions made by the administrator of the GCCF, who was remunerated by BP itself, and opted to pursue their claims in court rather than accept payment from the GCCF. ${ }^{210}$ The Department of Justice expressed concerns regarding the inconsistent outcomes in respect of claimants who were similarly situated. ${ }^{211}$ An independent review uncovered instances in which the GCCF made errors in the claims evaluation process but found that, for the most part, the GCCF had applied its protocols and methodologies consistently. ${ }^{212}$ In respect of similarly situated claimants being met with different outcomes by the GCCF, the independent evaluation revealed that it may have been impacted by a number of factors, including a change in the methodologies of the GCCF while it operated. ${ }^{213}$ The independent evaluation of the GCCF claims process revealed that approximately 7300 claimants were negatively impacted by errors (such as underpayment and claims being denied), requiring the GCCF to make additional payments and/or first payments of more than $\$ 64$ million. ${ }^{214}$

206 GCCF "Final Rules Governing Payment Options, Eligibility, and Substantiation Criteria and Final Payment Methodology" (2011) 2-3 https://eng2viet.files.wordpress.com/2011/02/gccf-final-rules.pdf (30-07-2020).

207 BDO Consulting (n 189) 71.

208 ibid 60.

209 ibid.

210 ibid.

211 ibid 71.

212 ibid 58.

213 ibid 72.

214 ibid. 
In 2010, the Judicial Panel on Multidistrict Litigation (JPML) centralised all federal actions in the United States District Court for the Eastern District of Louisiana. ${ }^{215}$ This led to the consolidation of thousands of individual claims, including private claims for economic loss and property damage, with this multidistrict litigation. ${ }^{216}$ In February 2011, BP began settlement negotiations with the plaintiffs in the class action lawsuit In Re: Spill by the Oil Rig "Deepwater Horizon" in the Gulf of Mexico on April 20, 2010, which was pending in the United States District Court for the Eastern District of Louisiana. ${ }^{217}$ On 2 March 2012, the parties reached an in-principle agreement for two class action settlements, a Medical Claims Settlement and an Economic and Property Damages Settlement, which are of relevance for this discussion. ${ }^{218}$ As part of the litigation In Re: Spill by the Oil Rig "Deepwater Horizon", the District Court Judge Carl Barbier issued a transition order, on 8 March 2012, for the transition from the GCCF claims process to a court-supervised Settlement Programme with its own framework for processing claims as established by the Economic and Property Damage Settlement. ${ }^{219}$ According to that order, the GCCF would no longer admit, process or pay any claims other than the claims for which final payment had already been accepted by the claimant and which were not pending appeal, all other claims having to be submitted under the Settlement Programme. ${ }^{220}$ The transition order also terminated the GCCF appeal process for all claims unless still pending. ${ }^{221}$ In December 2012, a District Court order was issued granting the final approval of the Economic and Property Damages Settlement, confirming a class-wide release and barring class members from instituting legal action against $\mathrm{BP}^{222}$

215 In Re Oil Spill by the Oil Rig "Deepwater Horizon" in the Gulf of Mexico, on April 20, 2010 MDL No 2179 Order and Reasons (Document: 8138) 1.

216 ibid.

217 ibid 2. See also BDO Consulting (n 189) 56.

218 In Re Oil Spill (n 219) 2; BDO Consulting (n 189) 56-57.

219 In Re Oil Spill (n 219) 3; BDO Consulting (n 189) 56-57.

220 BDO Consulting (n 189) 56-57.

221 ibid 57.

222 In Re Oil Spill by the Oil Rig "Deepwater Horizon" in the Gulf of Mexico, on April 20, 2010 MDL No 2179 Order and Judgement (Document: 8139) 1,3, 4 . 
The Economic and Property Damages Settlement aims to settle all claims by private individuals and entities who suffered economic loss and property damage as a result of the Deepwater Horizon incident. ${ }^{223}$ In terms of the Settlement, the class consists of individuals and businesses defined by geographic zones (ranging from most impacted to least impacted) and the nature of their loss or damage. ${ }^{224}$ The geographic bounds are Gulf Coast areas (Louisiana, Mississippi, Alabama, certain coastal counties in east Texas and west Florida) including specified adjacent Gulf waters. Individuals must have "lived, worked, owned property" in the specified zones, while businesses must have conducted business within the specified zones, within a specified time period. ${ }^{225}$ The Settlement recognises six categories of damage: (1) economic loss (covering claims by businesses and individuals who suffered a loss of income or profits as a result of the Deepwater Horizon incident); (2) property damage (which includes the loss of use/enjoyment of real property and covers property damage of coastal property and wetlands property, including property sales loss); (3) vessel of opportunity ("VoO”) charter payment; (4) vessel physical damage; (5) subsistence damage (which covers claims for loss of subsistence from those who fished or hunted in the region to harvest, catch, barter, consume or trade Gulf resources, including seafood and game, in a traditional or customary manner, to sustain their basic or family dietary, financial security, shelter, tool or clothing needs, and who relied upon subsistence resources that declined in the region due to the Deepwater Horizon incident); and (6) seafood compensation covered by its own fund of $\$ 2.3$ billion (including claims by eligible commercial fishers, seafood boat captains, seafood crew, oyster leaseholders and seafood vessel owners who have their home port or landed seafood on the Gulf Coast, including damages suffered by oyster leaseholders). ${ }^{226}$ The Settlement presumes causation for certain zones and/or industries more likely to have been impacted by the spill on the basis that these industries would prove causation in litigation. In those cases,

223 In Re Oil Spill (n 219) 6. See also In Re Oil Spill by the Oil Rig "Deepwater Horizon" in the Gulf of Mexico, on April 20, 2010 MDL No 2179 Preliminary Approval Order (Document: 6418) 4.

224 In Re Oil Spill by the Oil Rig "Deepwater Horizon" in the Gulf of Mexico, on April 20, 2010 MDL No 2179 Order and Judgement (Document: 8139) Appendix A: Class Definition A-1. See also In Re Oil Spill (n 223) 5.

225 ibid.

226 In Re Oil Spill (n 215) 10-16. 
the claimants are only required to prove that they suffered a financial loss and need not prove a causal link between their loss and the Deepwater Horizon incident. ${ }^{227}$

Since the court's approval of the Settlement, BP has challenged the claims administrator's interpretation thereof resulting in protracted litigation over many years. According to BP, the claims administrator's misinterpretation of the terms of the Settlement has resulted in the payment of "artificial claims" where the claimant's loss is not linked to the Deepwater Horizon incident, the losses have been inflated and/or there are no losses at all. ${ }^{228} \mathrm{BP}$ asserted that this misinterpretation led to obscure results and was not aligned with the goal of the Settlement, which is to compensate actual loss of profits rather than artificial claims by unaffected claimants. ${ }^{229}$ In this respect two issues raised by BP merit mention. Firstly, BP was displeased with the method according to which losses were calculated, because the financial statements of the claimants were not in all instances being properly "matched" (their expenses were not being matched to their revenue). ${ }^{230}$ Secondly $\mathrm{BP}$ was dissatisfied that presumed causation resulted in claimants not having to show any causal link between their loss and the incident. ${ }^{231}$ After extended litigation the issue of matching was addressed, the claims administrator was directed to match the revenue and expenses of claimants and to draft a policy in this regard. ${ }^{232}$ In respect of causation BP's request to change the terms of the Settlement was rejected, the rejection was affirmed on appeal and BP was held to be bound by the settlement which the parties negotiated. ${ }^{233}$ Only recently, in respect of causation, the Fifth Circuit held that where credible evidence of an intervening

227 ibid 12.

228 Lake Eugenie Land \& Dev Inc v BP Exploration \& Prod Inc (In re Deepwater Horizon) No 13-30315 (5th Cir Nov 5 2013), consolidated with In Re: Deepwater Horizon No 13-30329 (5th Cir 2013) (Document: 00512394834) 7,9 and 25.

229 ibid 9.

230 ibid 6 and 13-19. See also Lake Eugenie Land \& Dev Inc v BP Exploration \& Prod Inc (In re Deepwater Horizon) No 1730727 (5th Cir June 26 2019) 4.

231 Lake Eugenie (n 228) 4-6.

232 Lake Eugenie (n 228) 4. See "Policy 495", which sets out two categories of methods for the matching of financial statements. One group of methodologies, namely the industry-specific methodologies ("ISMs"), which enables the administrator to "reallocate" or "smooth" the claimants' otherwise large profits on an industry-wide basis, was rejected by the Fifth Circuit. By contrast, the other method, namely the annual variable margin methodology ("AVMM"), which allows expenses and corresponding revenue to be recorded in the same month, regardless of when the expenses were incurred, was accepted. See at 3-6 and 8-9.

233 Lake Eugenie (n 228) 4. 
(superseding) cause can be shown the claimant's attestation can be examined. ${ }^{234}$ On this basis an award of $\$ 77$ million was reversed because BP was able to show that the claimant's loss resulted from an increase in the price of fertilizer rather than the Deepwater Horizon incident. ${ }^{235}$ This decision may provide BP with partial relief against "artificial claims" caused by presumed causation, in that at least where credible evidence of an intervening cause can be shown the claimant's attestation of a loss may be further investigated.

The difficulties faced by GCCF in admitting claims for pure economic loss indicate how complex determining the exact "causal nexus" required between the spill and the loss becomes when large numbers of claims are submitted. It also highlights how important clear causation rules or policies establishing the required link between the contamination and the loss are. The inconsistencies in the GCCF's admission of claims of claimants who are similarly situated further highlights the importance of interpreting and applying the same rules and policies consistently and throughout. The protracted litigation following the court's approval of the Economic and Property Damage Settlement emphasises the importance of interpreting and applying policies in a manner that precludes the payment of artificial and/or inflated claims. Large-scale spills raise social and political considerations and garner far greater publicity, which may influence the number of claims submitted and may lead to claimants submitting claims solely on the basis of public perception rather than actual impact by the spill. The latter is a cause for concern and further increases the importance of approaching claims for economic loss resulting from an oil spill (especially a large spill) with consistency. Inconsistencies in admitting claims for pure economic loss can result in protracted litigation. ${ }^{236}$ For those reasons, in instances of large-scale spills with a multitude of claims for pure economic loss, the courts of the tates parties to CLC 1992 and FUND 1992 must be careful to ensure consistency in their decisions and consistency with the Fund's criteria. Likewise, the courts in States parties should ensure that "artificial" and/or inflated claims for pure economic loss are 
not admitted. The Fund's criteria (where applied) should be interpreted so as to exclude such claims. Large-scale, or a multitude of artificial and/or inflated claims for pure economic loss could potentially affect the Fund's viability where the Fund's involvement becomes necessary. The approach followed in the case of the GCCF should arguably not be followed because it was backed by a $\$ 20$ billion trust fund and an open-ended commitment, which were unique and made it possible for the GCCF administrator to apply liberally the proximate cause test. ${ }^{237}$

\section{THE MARINE POLLUTION ACT'S COVERAGE OF NON-PERSISTENT-OIL AND NON-TANKER-OIL POLLUTION DAMAGE}

As previously explained, the CLC 1992 and FUND 1992 regimes only cover persistent-oil pollution from tanker vessels. ${ }^{238}$ The regime does not cover bunker-oil pollution discharged from a non-tanker vessel and non-persistent-oil pollution. In South Africa, bunker-oil pollution damage caused by non-tanker vessels and pollution damage caused by non-persistent oil is presently covered by the Marine Pollution Act, which defines the terms "ship" and "oil" more broadly than the Civil Liability Act. The Marine Pollution Act defines the term "ship" so as to include "any kind of vessel or other sea-borne object from which oil can be discharged". ${ }^{239}$ The words "any kind of vessel" and "sea-borne object" are broad enough to encompass a wide range of non-tanker vessels such as, for example, bulk carriers, container ships, general cargo ships, cruise ships and other vessels carrying passengers, tugs, dredgers, car carriers, fishing vessels, diving support vessels and drill ships previously mentioned.

In addition, the Marine Pollution Act applies to non-persistent-oil pollution because it defines the word "oil" expansively as "any kind of mineral oil [including] spirit produced from oil and a mixture of such oil and water or any other substance". ${ }^{240}$ The words "any kind of mineral oil" are broad enough to

237 Davis (n 185) 38.

238 art 1(5) of CLC 1992.

239 s 1.

240 ibid. 
encompass both persistent and non-persistent mineral oil. In addition, the Marine Pollution Act applies to harmful substances, which are defined to include oil and any other substance subject to control by the 1973 International Convention for the Prevention of pollution from Ships ${ }^{241}$ as modified by its 1978 Protocol ("MARPOL 1973/78") 242 as well as "mixtures of such substances and water or any other substance". ${ }^{243}$ MARPOL 1973/78 defines "oil" as "petroleum in any form including crude oil, fuel oil, sludge, oil refuse and refined products" other than petrochemicals. ${ }^{244}$ The Marine Pollution Act therefore applies to many forms of oil, including non-persistent oil. In other words, where CLC 1992 through its incorporation by means of the Civil Liability Act does not apply to the form of oil pollution or type of vessel involved, the Marine Pollution Act will apply.

The Marine Pollution Act is a combination of CLC 1969 and MARPOL 1973. ${ }^{245}$ Modelled partly on CLC 1969, the Marine Pollution Act imposes strict liability on ship owners for oil pollution damage, ${ }^{246}$ with limited exceptions. ${ }^{247}$ Strict liability is channelled exclusively to the ship owner and victims are barred from claiming against the servants and/or agents of the ship owner under the Marine Pollution Act or otherwise. ${ }^{248}$ Furthermore, because ship owners incur strict liability, they can limit the extent of their liability to 133 SDR per tonne or 14 million SDR, whichever amount is smaller. ${ }^{249}$ The compulsory insurance provisions in the Marine Pollution Act have been repealed by the Civil Liability Act, but the latter Act only applies to tankers. ${ }^{250}$ There is thus no assurance of

2411340 UNTS 184, (1973) 12 ILM 1319. Adopted: 02-11-1973; EIF: 10-02-1983.

2421340 UNTS 61, (1978) 17 ILM 546. Adopted: 17-02-1978; EIF: 02-10-1983.

243 s $1(1)$.

$244 \operatorname{reg} 1(1)$ of Annex I. See also Appendix I to Annex I.

245 Hare (n 43) 560.

246 s $9(1)(a)-(c)$.

247 In terms of s 9(3), ship owners are exempt from liability where the "loss, damage or costs": “(a) resulted from an act of war, hostilities, civil war, insurrection or an exceptional, inevitable and irresistible natural phenomenon; or (b) was wholly caused by an act or omission on the part of any person, not being the owner or a servant or agent of the owner, with intent to do damage; or (c) was wholly caused by the negligence or other wrongful act of any government, or other authority responsible for the maintenance of lights or other navigational aids in the exercise of that function".

248 s $10(2)$.

249 s $9(5)$.

250 s 17 read with the schedule to the Civil Liability Act. 
payment accompanying the strict, but limited, liability imposed on ship owners for oil pollution damage by the Marine Pollution Act. While ship owners may elect to take out insurance, it appears that vessel owners (with the exception of tanker owners) have no obligation to do so.

There is no fund accompanying the Marine Pollution Act. As a result, where the ship owner is exempt from liability, unable to meet its financial obligations or the damage exceeds the limits on the ship owner's liability, victims of oil pollution damage may be under-compensated or not compensated at all. The victims could claim from contributing parties who are not regarded as "servants or agents" of the ship owner, such as the oil cargo interests. However, in the absence of strict liability, proof of the contributing parties' liability and the extent thereof is required, something which may hinder or delay compensation.

Under the Marine Pollution Act, ship owners can only be prevented from limiting their liability if it is shown that the damage was "due to the fault of the owner or with the knowledge or concurrence of the owner". ${ }^{251}$ This means that it is easier to prevent ship owners from capping their liability under the Marine Pollution Act than under the Civil Liability Act. Indeed, proving that the owner knew the "damage would probably ensue" is a more onerous burden to bear than simply showing fault or privity on the part of the ship owner. It is therefore more likely that a ship owner will be prevented from limiting his, her or its liability under the Marine Pollution Act.

A major shortcoming of the Marine Pollution Act is that it only applies strict liability to pollution damage within South Africa, which is defined to include its territorial waters. ${ }^{252}$ The Act does not apply strict liability to incidents occurring within South Africa's EEZ, meaning that, in instances of non-tanker or non-persistent-oil pollution in that zone, strict liability does not apply.Victims of such pollution damage therefore have to prove the fault of the responsible party or parties, something which, as previously mentioned, may turn out to be a difficult, lengthy and costly endeavour hindering compensation.

251 s 10(4). The ship owner may not limit its liability where the damage resulted from a wilful act or omission of the owner.

252 s $9(1)$ (a) read with s 1. 
While, pending the introduction of new legislative measures and its repeal, the Marine Pollution Act with all its shortcomings continues to regulate bunkeroil pollution damage as well as non-persistent-oil pollution damage in South Africa, the 2001 International Convention on Civil Liability for Bunker Oil Pollution Damage (BUNKERS 2001)253 can address the shortcomings of the Act in respect of bunker-oil pollution damage and the 1996 International Convention on Liability and Compensation for Damage in Connection with the Carriage of Hazardous and Noxious Substances by Sea ${ }^{254}$ (HNS 1996) as amended by its 2010 Protocol $^{255}$ (2010 HNS Convention) ${ }^{256}$ can provide a solution in respect of nonpersistent-oil pollution damage. These conventions are examined below.

\section{THE APPLICATION OF BUNKERS 2001 TO BUNKER- OIL POLLUTION DAMAGE}

BUNKERS 2001 was adopted to provide effective compensation to victims of bunker-oil pollution damage. Claims relating to bunker-oil pollution represents nearly half of the total amount of oil pollution claims globally, ${ }^{257}$ making the Convention an essential aspect of the international compensation regime for shipsourced oil pollution. BUNKERS 2001 is modelled on CLC 1992 in that it lays down strict liability for ship owners, entitles ship owners to limit their liability under an applicable national or international regime and requires compulsory insurance in respect of bunker-oil pollution. ${ }^{258}$ To date, South Africa has not acceded to BUNKERS 2001. The latter defines "bunker oil" as "any hydrocarbon mineral oil, including lubricating oil, used or intended to be used for the operation or propulsion of the ship, and any residues of such oil". ${ }^{259}$ BUNKERS 2001 defines a "ship" as "any seagoing vessel and seaborne craft, of any type whatsoever"

253 (2001) 40 ILM 1493. Adopted: 23-03-2001; EIF: 21-11-2008.

254 (1996) 35 ILM 1415. Adopted: 03-05-1996; EIF: not yet.

255 adopted: 30-04-2010; EIF: not yet. The text of the Protocol is available at https://www.hnsconvention.org/wpcontent/uploads/2019/04/2010-HNS-Protocol_e.pdf (02-09-2020).

256 The consolidated text is available at http://www.imo.org/en/OurWork/Legal/HNS/Documents/HNS\%20

Consolidated\%20text.pdf (02-09-2020).

257 Wu "Liability and compensation for bunker pollution" 2002 J Mar L E Com 553555.

258 art 3,6 and 7.

259 art $1(5)$. 
excluding vessels or seaborne crafts not fuelled by bunker oil and tankers. ${ }^{260}$ BUNKERS 2001 is therefore applicable to bunker-oil pollution from a broad range of ships currently regulated by the Marine Pollution Act in South Africa.

BUNKERS 2001 has a wider geographical application than the Marine Pollution Act in that it extends to a state's EEZ or equivalent area. ${ }^{261}$ This means that South Africa's accession to BUNKERS 2001 would introduce strict liability for bunker-oil pollution damage occurring in South Africa's EEZ and the incorporation of its provisions into domestic law would make it possible for the victims of bunker-oil pollution in the EEZ to benefit from the strict liability regime and, therefore, no longer have to prove liability or the extent of the responsible parties' liability.

In addition, BUNKERS 2001 defines the term "ship owner" more broadly than the Marine Pollution Act to include "the registered owner, bareboat charterer, manager and operator of the ship". ${ }^{262}$ The Convention therefore extends the strict liability to all the persons who are involved in the navigation and management of the vessel. There are thus a wider range of parties whom victims of bunker oil pollution are able to hold jointly and severally liable for victim reparation in terms of the Bunker Convention. ${ }^{263}$ This broad definition is highly beneficial because there is no accompanying fund to which a claimant can look for compensation where the ship owner in the narrow sense of the term is unable to meet his, her or its financial obligations or where the damage exceeds the limits of liability set out in the Convention. In other words, thanks to this broad definition, a claimant has at least a number of parties to whom it can turn for compensation in the case of any shortfall or where the registered ship owner is unable to meet his, her or its financial obligations. ${ }^{264}$ It should, however, be noted that only the registered ship owner of the vessel is required to take out insurance. ${ }^{265}$ This means that,

260 art 1(1).

261 art 2(a)(i)-(ii).

262 art $1(3)$.

263 Zhu "Can the Bunkers Convention Ensure Adequate Compensation for Pollution Victims" 2009 J Mar L E Com 1 3. 
while there is no assurance of payment when pursuing a claim against any of the other parties who are liable, the claimant has at least a number of parties whom it can hold jointly and severally liable for compensation and, where one party is insolvent, it can turn to the other. ${ }^{266}$ This is in contrast to the Marine Pollution Act, under which the victims of bunker-oil pollution can only turn to the registered ship owner and, where the latter is insolvent or otherwise unable to pay, they have no other recourse.

Furthermore, BUNKERS 2001 does not expressly set out a limitation on a ship owner's liability. Indeed, the Convention merely provides that it does not detract from a ship owner's right to limit its liability under a national or international regime, ${ }^{267}$ such as the 1976 Convention on the Limitation of Liability for Maritime Claims $^{268}$ as amended by its 1996 Protocol (LLMC 1996). ${ }^{269}$ The limits of liability are thus determined by an applicable national regime or LLMC 1996. The latter limits the ship owner's liability to claims for "loss of life or personal injury" and "other claims", a limitation that does not exclude claims for damage caused by bunker spills. ${ }^{270}$ The limitation, which was amended in $2012,{ }^{271}$ is set as follows: for "other claims" relating to ships not exceeding a gross tonnage of 2000 , liability is limited to 1.51 million SDR, for each tonne from 2001 to 30000 tonnes 604 SDR, for each tonne from 30001 to 70000 tonnes 453 SDR and for each tonne exceeding 70000 tonnes 302 SDR. This means that, for a vessel of 30000 tonnes, the amount recoverable is 1.51 million SDR + (604 SDR $\times 28000$ tonnes $)=$ 18422000 SDR, while for a vessel of 70000 tonnes the amount recoverable is $18422000 \mathrm{SDR}+$ (453 SDR per tonne x 40000 tonnes $)=36542000 \mathrm{SDR}$ and for a vessel exceeding 70000 tonnes an amount in excess of 36542000 SDR is claimable. This indicates that the amounts claimable under LLMC 1996 may be significantly higher than the total aggregate of 14 million SDR claimable under the Marine Pollution Act.

266 Zhu (n 263) 3.

267 art 6.

2681456 UNTS 221, (1977) 16 ILM 606. Adopted: 19-11-1976; EIF: 01-12-1986.

269 (1996) 35 ILM 1433. Adopted: 02-05-1996; EIF: 13-05-2004.

270 art 3.

271 Resolution LEG 5(99) 2012 on amendments to the 1996 Protocol. 
The LLMC 1996 limitations, however, only apply when the state involved has incorporated the Convention into its domestic law. In instances where it has not done so, LLMC 1996 is not applicable and the only limits available are those set in national legislation, if any. The extent of the ship owners' liability under BUNKERS 2001 is therefore left to be determined in each case on the basis of the applicable national or international regime. The fact that BUNKERS 2001 does not set limits on the ship owners' liability is seen as a shortfall of the Convention because ship owners and their insurers are not sure of the exact amounts to which the ship owners' liability may be limited, although the insurance need not exceed the limit on the ship owners' liability in LLMC $1996 .{ }^{272}$ In the absence of specified limits on liability, claimants under BUNKERS 2001 suffering similar loss or damage may be faced with significantly different limits on liability, depending on where the spill occurs and claims are instituted. ${ }^{273}$ Another downside is that there is no limitation fund under LLMC 1996 exclusively for bunker-oil pollution claims and those claims would have to compete with other limitable claims under the applicable regime. ${ }^{274}$ However, history reveals that there have been very few instances in which the claims of victims of bunker oil pollution damage had to compete with other claims under the LLMC 1996. ${ }^{275}$

South Africa, however, has not acceded to LLMC $1996^{276}$ and, as a result, the limits on liability set out therein do not apply. Should South Africa accede to Bunkers 2001 and incorporate it into domestic law, the existing limits on liability set out in national law will continue to apply rather than those provided in the LLMC 1996 until South Africa accedes to the LLMC 1996 and incorporates it into domestic law. The 14 million SDR limit in the Marine Pollution Act may thus continue to apply to bunker oil pollution damage, except if the provision containing this limitation is repealed by the legislation enacting BUNKERS 2001 into national law. Alternatively, a ship owner may limit its liability for loss or damage to property resulting from a single occasion, in the absence of any fault

272 art 7(1). See Wu (n 257) 562.

$273 \mathrm{Wu}(\mathrm{n} 257) 562$.

274 Wu (n 257) 564.

275 ibid.

276 See IMO (n 34) 393-394 
or privity, according to the general limitation in the Merchant Shipping Act. ${ }^{277}$ According to this general limitation a ship owner's liability for all claims for loss or damage to property only resulting from a single incident is limited to $66,67 \mathrm{SDR}$ for each tonne of the vessel. ${ }^{278}$ For a vessel of 2000 tonnes this limitation offers as little as 133340 SDR cover $(66,67$ SDR x $2000=133340$ SDR). This is far less cover for bunker oil pollution damage than the cover offered by the limits on a ship owner's liability in respect of a vessel of the same size in the LLMC 1996. The general limitation on a ship owner's liability set out in the Merchant Shipping Act is thus unlikely to provide suitable coverage for bunker oil pollution damage in South Africa. It would be useful for legislation enacting Bunkers 2001 into South African law to expressly increase the present limit of 14 million SDR for bunker oil pollution damage. Alternatively, South Africa could accede to and incorporate both BUNKERS 2001 and LLMC 1996 into domestic law. Nonetheless increased limits on liability to cater for large-scale bunker-oil pollution damage will prove extremely useful as the quantities of bunker oil transported by sea increase as international maritime trade grows. ${ }^{279}$

An added positive feature of BUNKERS 2001 is that it compels the registered owners of all ships in excess of 1000 tonnes to take out compulsory insurance 280 and carry evidence thereof on board. ${ }^{281}$ The insurance taken must cover the limits on liability set out under the applicable national or international limitation regime, but should, in all instances, not be greater than an amount calculated in accordance with the limits set out in LLMC 1996. ${ }^{282}$ In this regard, BUNKERS 2001 enables victims of oil pollution damage to take direct action against the insurer, an avenue which promotes compensation. ${ }^{283}$ In contrast, it has already been pointed out that the compulsory insurance provisions in the Marine Pollution Act have been repealed and ship owners other than tanker owners are not obliged to take out compulsory

277 s 261 Merchant Shipping Act 57 of 1951.

278 ibid.

279 UNCTAD (n 1) 1.

280 art 7(1).

281 art 7(2).

282 art 7(1).

283 ibid. 
insurance, and there is no accompanying right to take direct action against the insurer. The compulsory insurance provisions imposed by BUNKERS 2001, accompanied by the ability to take direct action against the insurer, are far more beneficial than those of the Marine Pollution Act, which does not impose such obligation.

Under the Marine Pollution Act, it is considerably easier for a claimant to prevent a ship owner from capping its liability than under BUNKERS 2001. As previously mentioned, under the Marine Pollution Act a claimant need only prove "actual fault or privity" on the part of the ship owner to prevent the owner from limiting its liability. ${ }^{284}$ By contrast, ship owners can only be prevented from limiting their liability on the basis of BUNKERS 2001 if "the pollution was a result of a personal act or omission, committed with the intent to cause such damage, or recklessly and with knowledge that such damage would probably result". ${ }^{285}$ As previously mentioned, having to prove that the ship owner knew that the "damage would probably result" is much more cumbersome than only proving fault or privity on the part of the ship owner. ${ }^{286}$ Although the fact that it is easier to prevent a ship owner from limiting its liability under the Marine Pollution Act can be seen as a positive feature thereof, it should be pointed out that unlimited liability of the ship owner would in any event not be accompanied by an assurance of payment and may thus prove to be of no value where the ship owner is insolvent.

Acceding to BUNKERS 2001 and incorporating it into our domestic law would address some of the shortfalls of the Marine Pollution Act. Indeed, strict liability for bunker-oil pollution would be extended to South Africa's EEZ and beneficial compulsory insurance provisions for all ships exceeding 1000 tonnes would be incorporated into domestic law. In addition, increased limits on liability such as those found in the LLMC 1996 can be introduced into South African law by expressly including such limits in the legislation enacting BUNKERS 2001 or by acceding to LLMC 1996 and incorporating it into national law. The limits on

284 s 10(6).

285 Art 6 of BUNKERS 2001 refers to LLMC 1996. See art 4 of LLMC 1976 as amended by LLMC PROT 1996. See art 9 of the LLMC PROT 1996.

286 s 10(4) of the Marine Pollution Act. 
a ship owner's liability in LLMC 1996 may prove more beneficial than the low limits on liability in the Marine Pollution Act.

\section{THE APPLICATION OF 2010 HNS CONVENTION TO NON-PERSISTENT-OIL POLLUTION DAMAGE.}

Although it is not a contracting State to HNS 1996, ${ }^{287}$ South Africa became in 2019 the fifth State to ratify or accede to HNS PROT 2010. ${ }^{288}$ This is not an issue because, in terms of the latter's article 18(1), once the Protocol comes into effect, HNS 1996 and HNS PROT 2010 will, as between the parties to the Protocol, "be read and interpreted together as one single instrument".

2010 HNS Convention defines a ship as "any seagoing vessel and seaborne craft" of any type whatsoever, ${ }^{289}$ a definition that is broad enough to cover a wide range of vessels and does not refer only to tankers. The Convention covers hazardous and noxious substances which includes oils, other liquid substances defined as noxious or dangerous, liquefied gases, liquid substances with a flashpoint not exceeding $60^{\circ} \mathrm{C}$, dangerous and hazardous and harmful substances (carried in packaged form or in containers) and solid bulk material possessing chemical hazards. ${ }^{290}$ The Convention does not cover persistent-oil pollution damage, which is regulated by CLC 1992, ${ }^{291}$ but it covers non-pollution damage caused by persistent oil, such as damage caused by a fire or explosion. ${ }^{292}$ Because 2010 HNS Convention will cover a broad range of oils (namely those defined in regulation 1 of Annex I of MARPOL), including non-persistent oils, ${ }^{293}$ once it is incorporated into South African domestic law and the overlapping provisions in the Marine

287 IMO (n 34) 497.

288 ibid 501.

289 art 1(1) of 2010 HNS Convention.

290 IMO “The HNS Convention Why it is needed” (2016) 3 http://www.imo.org/en/MediaCentre/HotTopics/ Documents/HNS\%20ConventionWebE.pdf (29-07-2020). See also the definition of hazardous and noxious substances in art 1(5), which covers a broad range of substances.

$291 \operatorname{art} 4(3)(a)$.

292 IOPC “An overview of the International Convention on the Liability and Compensation for Damage in Connection with the Carriage of Hazardous and Noxious Substances by Sea, 2010 (The 2010 HNS Convention)" (2018) 1 https://www.hnsconvention.org/wp-content/uploads/2018/08/HNS-Convention-Overview_e.pdf (2907-2020).

293 art 1(5)(a)(i) read with appendix I of Annex I to MARPOL 1973/1978. 
Pollution Act are repealed, it will provide cover for claims relating to pollution caused by all the non-persistent oils which are not covered by CLC 1992 and BUNKERS 2001. The incorporation of 2010 HNS Convention would also result in strict liability for persistent-oil pollution damage being extended to South Africa's EEZ. ${ }^{294}$ The Marine Pollution Act, which is currently applicable until it is repealed, only imposes strict liability for non-persistent-oil pollution damage caused in South Africa's territory and territorial waters and does not extend to the EEZ.

2010 HNS Convention is modelled on CLC 1992, together with FUND 1992. ${ }^{295}$ The Convention channels strict liability (with limited exceptions) to vessel owners in cases where damage is caused by an incident involving a hazardous and noxious substance (HNS), provided that there is a causal link between the damage and the HNS carried on board. ${ }^{296}$ The owner of a ship that carries HNS is entitled to limit his, her or its liability ${ }^{297}$ and is obliged to take out insurance to cover the limits on that liability. ${ }^{298}$ In turn, victims of oil pollution damage caused by an HNS may pursue their claims directly against the insurer. ${ }^{299}$ These provisions would be a largely beneficial introduction because compulsory-insurance provisions no longer apply in South Africa in respect of non-tanker vessels. The strict liability and compulsory-insurance provisions in 2010 HNS Convention offer the first tier of compensation for victims of damage caused by an HNS, while a second tier of compensation will be offered by the International Hazardous and Noxious Substances Fund (HNS Fund). ${ }^{300}$ The HNS Fund will be financed by entities receiving HNS substances within the States parties, like the contributions to the Fund, and those contributions will be calculated according to the quantities of HNS received within each state party in a calendar year. ${ }^{301}$ The HNS Fund will pay out where the vessel owner is exempt from liability, incapable of meeting

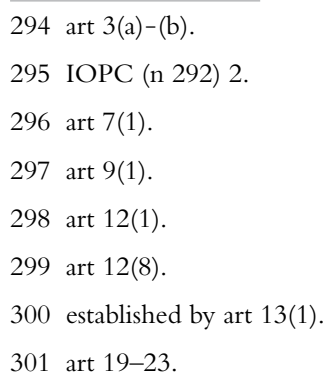


its financial obligations or because the damage exceeds the limits of liability, ${ }^{302}$ with the maximum amount of compensation payable for a single incident under the HNS Fund being set at 250 million SDR, including the sum paid by the vessel owner (or its insurer). ${ }^{303}$ This aggregate amount far exceeds the 14 million SDR recoverable for a single incident under the Marine Pollution Act. This is one reason in support of incorporating 2010 HNS Convention into South African domestic law. Another reason is that non-persistent-oil pollution damage will be covered by a Fund, thereby offering an assurance of payment that is currently not offered under the Marine Pollution Act.

In addition, 2010 HNS Convention will apply more broadly than CLC 1992, together with FUND 1992, because it will not only cover pollution damage caused by an HNS, but also the loss of life, personal injury and damage to property, loss or damage caused by contamination of the environment, the loss of income resulting from such contamination and the costs of preventative measures. ${ }^{304}$

To sum up, 2010 HNS Convention will address the shortfalls of the Marine Pollution Act in respect of non-persistent-oil pollution damage. The geographical scope of application of the Convention to a more extended geographical area, the higher limitations on the ship owner's liability and the provisions enabling direct action against the insurer will improve the coverage of non-persistent-oil pollution damage in South Africa. Most importantly, strict liability will be introduced for non-persistent-oil pollution damage in South Africa's EEZ and the victims of such pollution damage will no longer need to prove the vessel owner's liability.

\section{CONCLUSION}

The South African liability and compensation regime for ship-sourced oil pollution damage has been significantly improved by the domestic force given to CLC 1992 and FUND 1992. CLC 1992 and the Fund regime applicable to tanker-oil pollution has a number of positive aspects such as its application to an extended geographical area, strict liability for tanker-oil pollution, compulsory

302 art 14(1).

303 art $14(5)(a)$.

304 art 1(6). 
insurance and the right of direct action against the insurer. In addition, the caps on a tanker owner's liability for pollution damage caused in South Africa have been increased by CLC 1992 and the Fund regime. The compensation regime is supported by the financial backing offered by the Fund. The compensation regime could, however, be further improved through South Africa's accession to FUND PROT 2003. Until South Africa does so, the costs of a large oil spill exceeding the limits of the CLC 1992 and the Fund regime will not be covered sufficiently. This means that, in such instances, numerous victims may go uncompensated or undercompensated. Furthermore, the Marine Pollution Act that currently fills the gap in respect of non-persistent and non-tanker bunker-oil pollution damage has a number of shortfalls such as its limited territorial application and its low limits of liability. Thus, until South Africa accedes to BUNKERS 2001, incorporates it into domestic law and repeals any overlapping provisions in the Marine Pollution Act, the latter, with its shortfalls, will continue to regulate bunker-oil pollution damage in South Africa. At the same time, non-persistent-oil pollution damage will also continue to be regulated by the Marine Pollution Act until the 2010 HNS Convention comes into force, is incorporated into domestic law and the overlapping provisions in the Marine Pollution Act are repealed. In other words, while the South African liability and compensation regime for oil pollution damage has numerous positive features, it can still be improved through the accession to BUNKERS 2001 and the incorporation of the 2010 HNS Convention into domestic law once it comes into force. This will ensure that victims of bunkeroil pollution and other oil pollution from non-tanker vessels are able to benefit from the application of strict liability in an extended geographical area, from the compulsory-insurance obligations placed on the ship owner and the accompanying right to take action against the insurer as well as guaranteed increased limits on the ship owners' liability under HNS 2010 and the possible increased limits through acceding to and enacting both BUNKERS 2001 and LLMC 1996 into domestic law. Likewise, accession to FUND PROT 2003 will offer victims of tanker-oil pollution damage the highest level of cover for the compensation of their losses. 